\title{
The Gravina Sequence: Remnants of a Mid-Mesozoic Oceanic Arc in Southern Southeast Alaska
}

\author{
Charles M. Rubin' ${ }^{1}$ and Jason B. Saleeby
}

\author{
Division of Geological and Planetary Sciences, California Institute of Technology, Pasadena
}

\begin{abstract}
Fragments of Upper Jurassic to Lower Cretaceous volcanic and basinal strata constitute the Gravina belt in southeast Alaska. In the Ketchikan area the Gravina belt is made up of two lithotectonic units. The lower unit consists of coarse marine pyroclastic and volcaniclastic strata, mafic flows, breccia, and finegrained tuff which are locally intruded by hypabyssal bodies of diorite and quartz dionite. The volcanic rocks are characterized by tholeiitic arc basalts, lack felsic volcanic strata, and overlie Upper Triassic and older strata of the Alexander terrane. Augite and/or homblende-bearing porphyritic rocks are common and locally intrude the Alexander terrane basement, where they are thought to represent the intrusive equivalents of lavas within the section. Age constraints for the volcanic unit, based on structural and stratigraphic relations with adjacent units, are late Middle to Late Jurassic. The Gravina belt upper unit consists of fine- to coarse-grained turbidites and related conglomeratic channel-fill deposits. The basinal rocks unconformably overlie Permian and Triassic rocks of the Taku terrane and remnants of the lower volcanic par of the Gravina sequence which overlie the Alexander terrane. The conglomerate units contain mostly volcanic and plutonic lithic clasts, some of which yield $\mathrm{Pb}$-U zircon ages of 154-158 Ma. The predominance of pyroclastic deposits interbedded with massive flows, tuff, breccia, and argillaceous turbidites, and the lithologic and chemical composition of the volcanic rocks indicate a submarine volcanic arc setting for the Gravina sequence. The basinal pyroclastic rocks are inferred to have been shed from submarine stratovolcanos during the Late Jurassic. Epiclastic rocks were deposited as submarine fans, derived in part from erosion of a magmatic arc. The presence of fine-grained tuffaceous turbidites implies ongoing, but distant, volcanism. The pyroclastic and volcaniclastic rocks represent remnants of a Late Jurassic oceanic arc constructed on a composite basement consisting of the Alexander and Taku terranes. The strata accumulated in an intra-arc basin on the eastem edge of the Alexander terrane. The volcanic and basinal rocks were deformed during a major mid-Cretaceous intra-arc contractional event, in conjunction with the emplacement of a distinctly younger, arc-related plutonic suite.
\end{abstract}

\section{INTRODUCTION}

The paleotectonic setting and stratigraphic affinity of variably deformed and metamorphosed Upper Jurassic to Lower Cretaceous metavolcanic and metasedimentary strata exposed for nearly $750 \mathrm{~km}$ along the eastem edge of the Alexander and Wrangellia terranes (Figure 1) [Berg et al., 1972)] have been the subject of much debate. These rocks are called the GravinaNutzotin belt [Berg et al., 1972] and consist of interbedded marine basaltic breccia, flows, tuff, and turbidites. The volcanic belt unconformably overlies both the Alexander and Wrangellia terranes [Berg et al., 1972; Monger and Berg, 1987], which collectively form the Insular composite terrane [Wheeler and McFeely, 1987; terrane II of Monger et al., 1982]. The Insular composite terrane, consisting of juvenile, mantle-derived volcanic arc and rift assemblages [Samson et al., 1989], had no paleogeographic relation to North America until Mesozoic time [Monger et al., 1982; Saleeby, 1983; Gehrels and Saleeby, 1987a]. Rocks that lie to the east of the Insular composite terrane belong to the Intermontane composite terrane [Wheeler and McFeely, 1987; terrane I of Monger et al. 1982], consisting of lower Paleozoic continentderived slope-and-rise deposits, upper Paleozoic to lower Mesozoic ensimatic arc assemblages that probably formed

\footnotetext{
${ }^{1}$ Also at Department of Geology, Stanford University, Stanford, Califomia.
}

Copyright 1991 by the American Geophysical Union. adjacent to North America [see summary by Rubin et al., 1990a]. This composite terrane was accreted to North America in Early to Middle Jurassic time [Monger et al., 1982] and thus formed the western margin of the North American continent during late Mesozoic time.

Recent tectonic syntheses of Mesozoic paleogeography have been limited by uncertainties regarding the stratigraphic and structural evolution of the Gravina belt [e.g., Monger et al., 1982; Pavlis, 1982; Plafker et al., 1989a]. The initial stratigraphic and tectonic relations between the Insular composite terrane and North America are obscured by midCretaceous polyphase deformation and metamorphism; thus the initial tectonic boundary is highly modified. For example, the timing and style of accretion of the Insular composite terrane to the western North American continental margin remains enigmatic. Gravina belt rocks play a critical role in addressing these tectonic questions, due to their unique stratigraphic and paleogeographic position along the eastern margin of the Insular composite terrane. If Gravina belt strata overlap both the Insular and Intermontane composite terranes, then a pre-Late Jurassic tie between the Insular superterrane and the western margin of North America is implied. One objective of this study of the Gravina belt is to provide a critical tie between the Insular superterrane and westem North America.

This paper presents new stratigraphic, structural, geochronologic and geochemical data on the Gravina belt in southem southeast Alaska. Although rocks of the Gravina sequence have been metamorphosed to greenschist and lower amphibolite facies, locally original bedding features are preserved. This study is based on detailed geologic mapping 


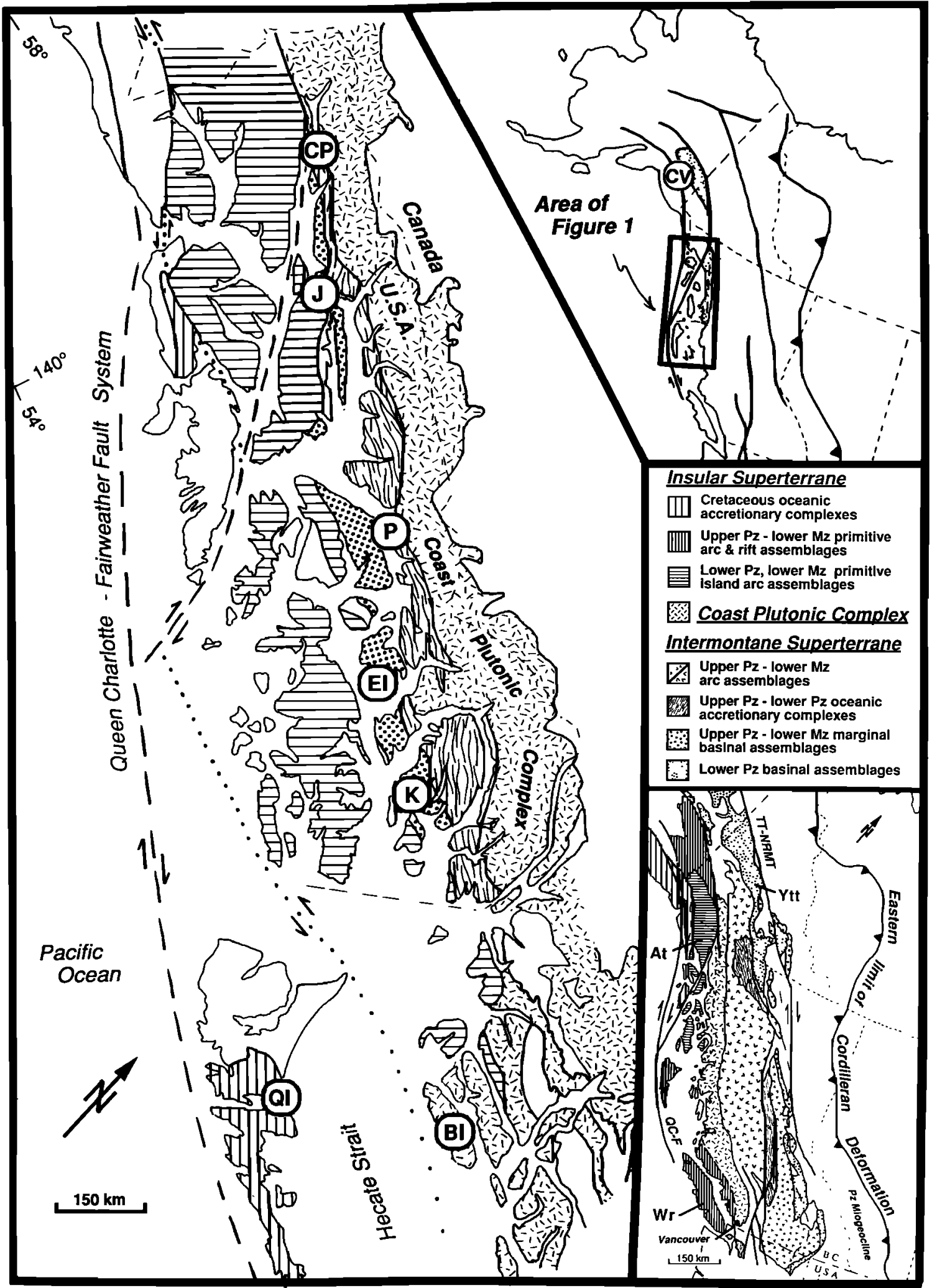

Fig.1. Location map of the Gravina sequence in the northwestem Cordillera, showing regions and features referred to in text. (Adapled from Beikman [1980] and Monger and Berg [1987]). Abbreviations are BI, Banks Island; CP, Chilkat Peninsula; EL, Etolin Island; J, Juneau; K, Ketchikan; P, Petersburg: and QI, Queen Charlotte Islands. Regional extent of the Gravina-Nutzotin belt shown in the upper right inset. CV is Chitna Valley. Location of major lithotectonic elements in the northem Cordillera shown in lower right inset. QC-F is the Queen Charlotte-Fairweather Fault System; TT-NRMT is the Tintina -Northem Rocky Mountain Trench System; Ytt is the Yukon-Tanana terrane; At is the Alexander terrane; and $W_{r}$ is Wrangellia. 


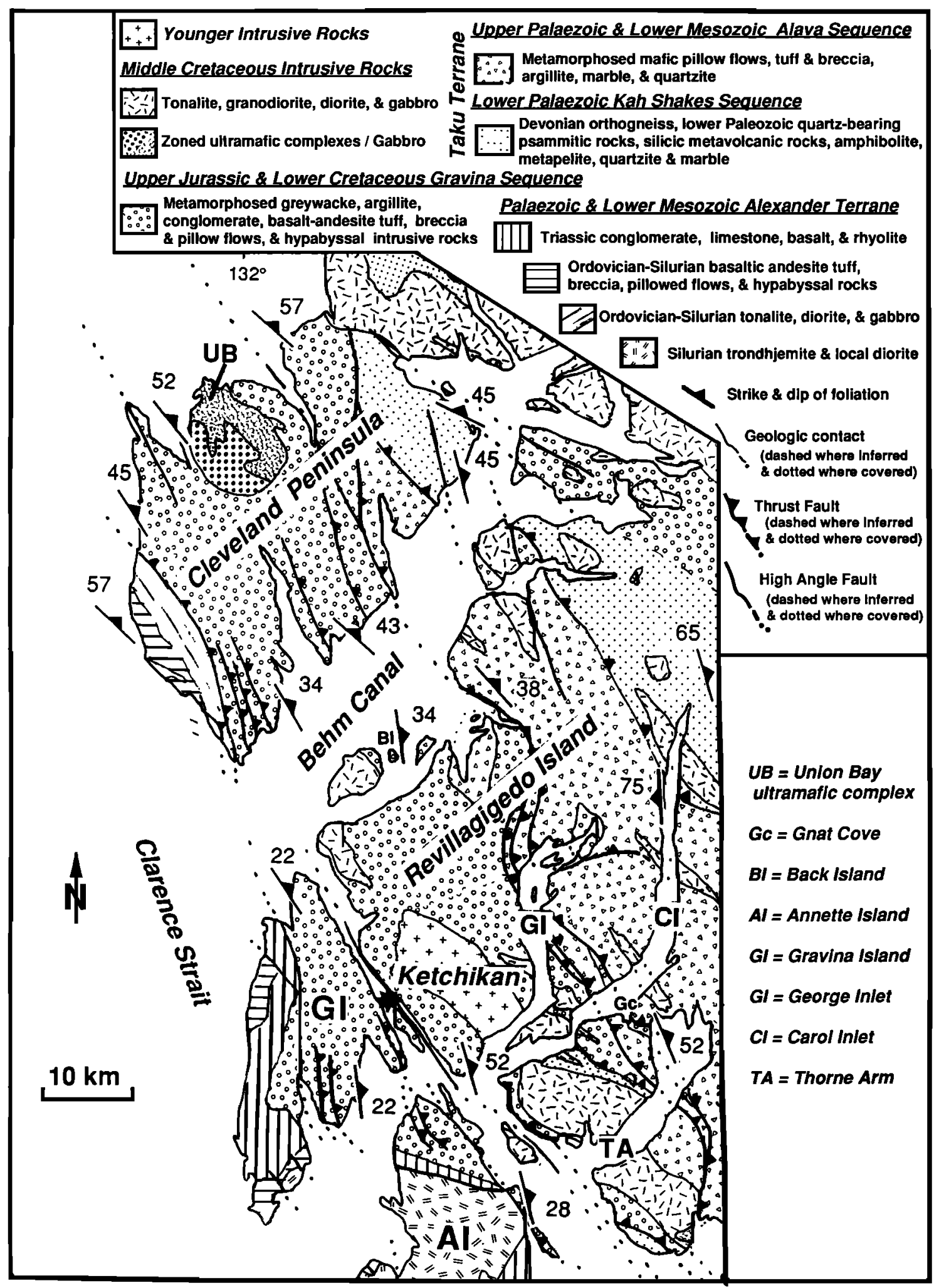

Fig. 2. Geologic map of Cleveland Peninsula, Revillagigedo Islands and adjacent islands. Adapted from Berg [1972, 1973] (parts of Annette and Gravina Islands], Gehrels and Saleeby [1987b] (parts of Annette, Duke, and Gravina islands], C. M. Rubin (unpublished mapping, 1985, 1986, 1987; Cleveland Peninsula and adjacent islands); C. M. Rubin and J.B. Saleeby (unpublished mapping, 1986, 1987, 1988; Revillagigedo and adjacent Islands).

along the shorelines of Annette, Gravina, and Revillagigedo islands, adjacent smaller islands, and Cleveland Peninsula (Figure 2). This paper characterizes the depositional setting of the Gravina sequence, provides a reference section for comparison to age-correlative volcanic sequences elsewhere in the Cordillera, and provides new constraints on mid-Mesozoic paleogeography and paleotectonic setting of the northwestern Cordillera. 


\section{PREVIOUS WORK}

Rocks of the Gravina belt in southeast Alaska were originally described by Buddington and Chapin [1929]. Studies by Gabrielse and Wheeler [1961] and Brew et al., [1966] have characterized the regional geologic relations and provided some of the first tectonic syntheses of this region. It was not until the early 1970 s that workers recognized the continuation of these Upper Jurassic to Lower Cretaceous volcanic and sedimentary rocks across the Chatham Strait fault into the Nutzotin belt of Yukon Territory and the eastern Alaska Range. In their pioneering study, Berg et al. [1972] named and defined the Gravina-Nutzotin belt, described the sedimentary and volcanic rocks along strike, provided fossil data of the age of the sequence, and provided a coherent geologic framework to interpret the belt using plate tectonic models. In southern southeastern Alaska, near the Ketchikan area, sedimentary and volcanic rocks assigned to the GravinaNutzotin belt were described by Brooks, [1902], Wright and Wright [1908], Smith [1915], Chapin [1918], Buddington and Chapin [1929], Berg [1973], and Berg et al. [1988].

\section{GEOLOGIC SETTING}

The Gravina-Nutzotin belt consists of a distinctive lithotectonic assemblage extending from the eastern Alaska Range to southernmost Alaska (Figure 1). It forms a narrow belt which, in general, separates the Alexander and Taku terranes [Berg et al., 1972; Monger and Berg, 1987]. The Taku terrane consists of polydeformed and metamorphosed mid to upper Paleozoic and Triassic strata that have recently been correlated with parts of the Intermontane superterrane [Rubin and Saleeby, 1991]. Gravina strata appear to depositionally overlie the Alexander terrane on Gravina Island [Berg, 1973; C.M.Rubin, unpublished mapping, 1985, 1986], Annette Island [C.M. Rubin, unpublished mapping, 1985, 1986], and on Kupreanoff Island [McClelland and Gehrels, 1990]; however, the contact is nowhere exposed at any of these localities. To the east, Gravina strata unconformably overlie metamorphosed and deformed rocks of the Permian and Triassic parts of the Taku terrane [Rubin and Saleeby, 1991; W.C. McClelland et al., Structural and Geochronological relations along the western margin of the Coast Mountains batholith: Stikine River to Cape Fanshaw, central southeastern Alaska, submitted to Journal of Structural Geology, 1991, hereinafter referred as McClelland et al., submitted manuscript, 1991a]]. To the north on the Chilkat Peninsula, Gravina strata unconformably overlie Upper Triassic strata of the northern Taku terrane of Monger and Berg [1987], interpreted as a displaced fragment of Wrangellia by Plafker et al. [1989b]. Gravina belt strata have not been identified within or east of the extensive crystalline rocks that underlie much of the Coast Mountains (Coast Plutonic Complex of Douglas et al. [1970].

\section{Alexander Terrane}

In southern southeast Alaska the Alexander terrane forms structural basement for most of the rocks that lie west of the Coast Plutonic Complex, including rocks of the Gravina sequence (Figure 2). The Alexander terrane consists of a structurally intact lower Paleozoic ensimatic arc sequence overlain by middle Paleozoic clastic and carbonate strata, and a Upper Triassic rift-related assemblage [Gehrels and Saleeby, 1987a]. In most areas, rocks of the Alexander terrane are only slightly deformed and are not highly metamorphosed, except near the eastern edge of the terrane where they are overprinted by late Mesozoic deformation [Rubin and Saleeby, 1987, Saleeby, 1987]. East of and apparently depositionally overlying the Alexander terrane lies the mid-Upper Jurassic to Lower Cretaceous Gravina belt.

\section{Taku Terrane}

Structurally overlying the Alexander terrane and Gravina belt is the Taku terrane. In the Ketchikan area the Taku terrane has two major lithologic components : (1) the upper Paleozoic and middle Mesozoic Alava sequence and (2) the mid-Paleozoic and older Kah Shakes sequence. The Alava sequence contains Pennsylvanian, Lower Permian, and middle Triassic shallow water limestone interbedded with and overlain by mafic aphyric flows, pillow breccia, pyroclastic strata, and quartzite [Silberling et al., 1981; Rubin and Saleeby, 1991]. Based on the similarities in lithologies and fossil ages, the Alava sequence may represent a highly metamorphosed and structurally fragmented part of the Yukon-Tanana and Stikine terranes [Rubin and Saleeby, 1991]. Locally, channel-fill deposits of the Gravina sequence unconformably overlie the Alava sequence and thus form an overlap between the Alexander terrane and the Alava sequence. The Kah Shakes sequence iocally occupies higher structural levels and consists of Dev'snian orthogneiss, silicic metavolcanic rocks, quartzrich metasediments, metabasalt, marble, calc-silicate, and quartzite. The quartz-rich metasedimentary rocks may be correlative with the lower Paleozoic portion of the YukonTanana terrane [Gehrels et al., 1990; Gehrels et al., 1991; Rubin and Saleeby, 1991; McClelland et al., submitted manuscript, 1991a] and record deposition on a slope and continental margin setting. Primary relations between the Kah Shakes and Alava sequences are uncertain; however, the presence of Alava crinoidal marble interlayered with quartzite that is lithologically similar to quartzite in the Kah Shakes sequences suggest an early depositional tie. Thus the Gravina sequence may overlap both the Alexander and Taku terranes.

\section{GRAVINA SEQUENCE}

\section{Definition and Distribution}

A revised stratigraphy is presented here for the southernmost part of the Gravina-Nutzotin belt, where it is exposed on Annette, Gravina, and Revillagigedo islands, and Cleveland Peninsula (Figure 2). Our data suggest that the ages and lithologies of the assemblage exposed in the Ketchikan area are atypical of the Gravina-Nutzotin belt exposed to the north in the Juneau area and in the eastern Alaska Range. Because of these differences, we informally use the term Gravina sequence to include all the Upper Jurassic to Lower Cretaceous rocks in the Ketchikan-Prince Rupert region. The revised stratigraphy includes the least deformed and metamorphosed rocks of the Gravina Formation and rocks that were previously thought to constitute part the Taku terrane by Berg et al. [1988].

The Gravina sequence consists of marine pyroclastic and volcaniclastic strata, argillite, greywacke, and conglomerate [Berg et al., 1988] and is intruded by plutons that range in composition from diorite to granodiorite. Locally, Alaskatype zoned ultramafic bodies intrude epiclastic rocks of the Gravina sequence. In the Ketchikan area the Gravina sequence 


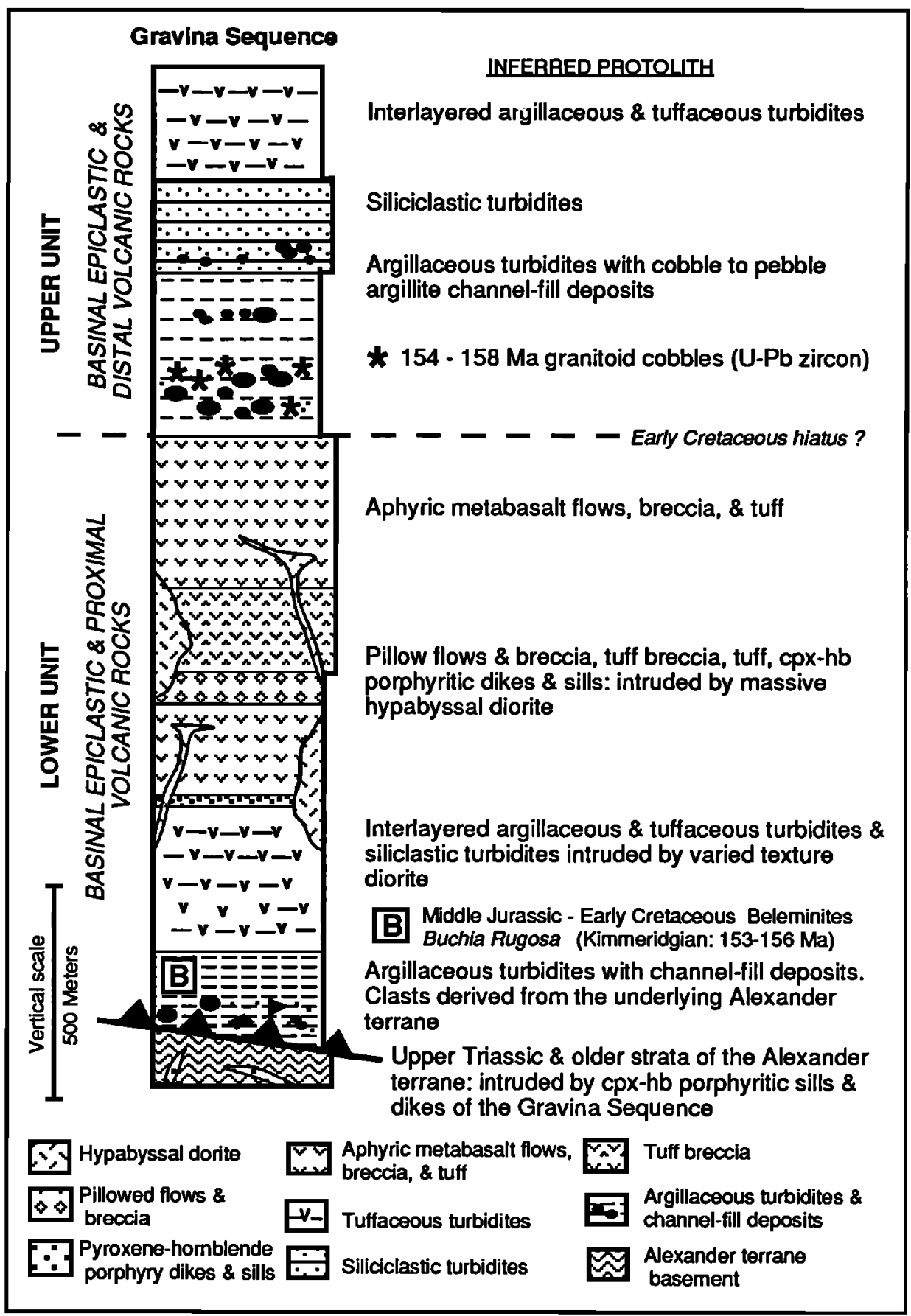

Fig. 3. Generalized stratigraphic section of the Gravina sequence on Gravina Island (Figure 2). The base of the section is in fault contact with the underlying Alexander terrane, and the top of the section is not seen in this area. On northwestem Annette and northern Gravina islands, similar strata unconformably overlie the Alexander terrane.

consists of two distinctive units: a lower dominantly volcanic unit and an upper dominantly epiclastic unit (Figure 3). The lower unit consists of coarse marine pyroclastic strata, mafic flows, breccia, and fine-grained tuff which are locally intruded by hypabyssal bodies of diorite and quartz diorite. Fine- to coarse-grained turbidites and related channel-fill deposits compose the upper unit of the Gravina sequence. This unit appears to lie unconformably upon the Alava sequence in some places, in other areas it lies on the lower volcanic unit of the Gravina sequence. The stratigraphic thickness of the Gravina sequence remains uncertain due to deformation and thrust faulting.

\section{Lower Unit}

Stratigraphy. The lower unit of the Gravina sequence is characterized by massive, cliff-forming basaltic breccia, flows, and tuff on Cleveland Peninsula and Gravina Island. This unit extends from the south on Annette Island to Gravina Island and Cleveland Peninsula in the north (Figure 2). The lower contact of this unit is not exposed, and at most localities 
the base of the Gravina sequence is in fault contact with the Alexander terrane [Brew and Karl, 1987]. On northwestern Annette Island and northern Gravina Island, clasts that are lithologically and petrographically identical to the underlying Triassic Hyd Group of the Alexander terrane are incorporated in Gravina argillite (Figure 4). The contact between the Gravina sequence and the Alexander terrane on these islands is interpreted as a faulted unconformity, based on the presence of these coarse detritus in the Gravina sequence. The top of the lower unit is designated at the base of the overlying tuffaceous and argillaceous turbidites and conglomerate. This stratigraphic contact is exposed on Gravina and Revillagigedo islands and on Cleveland Peninsula.

The lower unit has a structural thickness of $\sim 1300 \mathrm{~m}$ and is easily distinguished from similar lithologies in the Alexander terrane by the predominance of relatively fresh homblende and augite phenocrysts and the lack of near-pervasive Fecarbonate alteration in the flows, breccia, and tuffs. The lower unit consists of four lithologic subdivisions: (1) mudstone, calcareous argillite, conglomerate, and carbonate; (2) waterlaid coarse pyroclastic deposits and tuff; (3) lava flows; and (4) intrusive rocks (Figure 3 ).

A distinctive silicic- and carbonate-clast conglomerate is present at the base of the lower unit. The conglomerate consists of matrix- and locally grain-supported pebble- to cobble-sized, angular to subangular clasts of meta-rhyolite, metabasalt, limestone and dolomite that were derived from the underlying Alexander terrane. Conglomerate beds are lenticular in shape and are interbedded with planar laminated argillite and siltstone. The conglomerate is overlain by thinly laminated, black to grey argillite, siltstone, and shale. Siliciclastic rocks display centimeter-sized fining-upward sequences of siltstone-mudstone couplets.
Pyroclastic deposits and lava flows dominate the upper part of the lower unit (Figure 3). Pyroclastic deposits overlie argillite and occur in units generally less than $20 \mathrm{~m}$ in structural thickness, but thicknesses varies up to $500 \mathrm{~m}$. The coarse-grained pyroclastic flow breccias contain clasts as coarse as $\mathbf{4 0} \mathrm{cm}$ that are angular to subangular in shape. These deposits are generally monolithologic, with large hornblende and augite phenocrysts present in both the matrix and clasts; phenocrysts are up to $3 \mathrm{~cm}$ in diameter. Lithic fragments within the pyroclastic deposits consist of homblende-augite phyric angular to subangular clasts in a phyric or aphyric tuffaceous matrix. Subordinate pyroclastic deposits with aphyric matrix and clasts are also present. The proportion of matrix is generally $50 \%$, and clast-supported fabrics are rarely observed. Bedding is characteristically massive; however, tectonic deformation probably obscures original bedding features. A second category of volcanic deposits include crystal-rich tuff and tuffaceous argillite. These rocks consist of euhedral amphibole and augite, and rare feldspar phenocrysts in a pale green tuffaceous matrix containing augite, hornblende, epidote-clinozoisite, albite, quartz, and white mica. Typically the phenocrysts make up $10-15 \%$ of the rock. Locally, crystals occur in discrete layers or horizons. In places, dikes of hornblende-augite porphyry crosscut the interlayered argillite.

Pillowed and massive mafic to silicic flows make up the remaining part of the lower unit and are best exposed on southern Cleveland Peninsula. Typically, the mafic phyric flows are massive and are locally interlayered with black argillite. Homblende and/or augite-bearing porphyries intrude parts of the lower unit argillite and tuffaceous argillite. The phenocrysts and matrix of these dikes are compositionally similar to the phyric flows and tuff which are common within

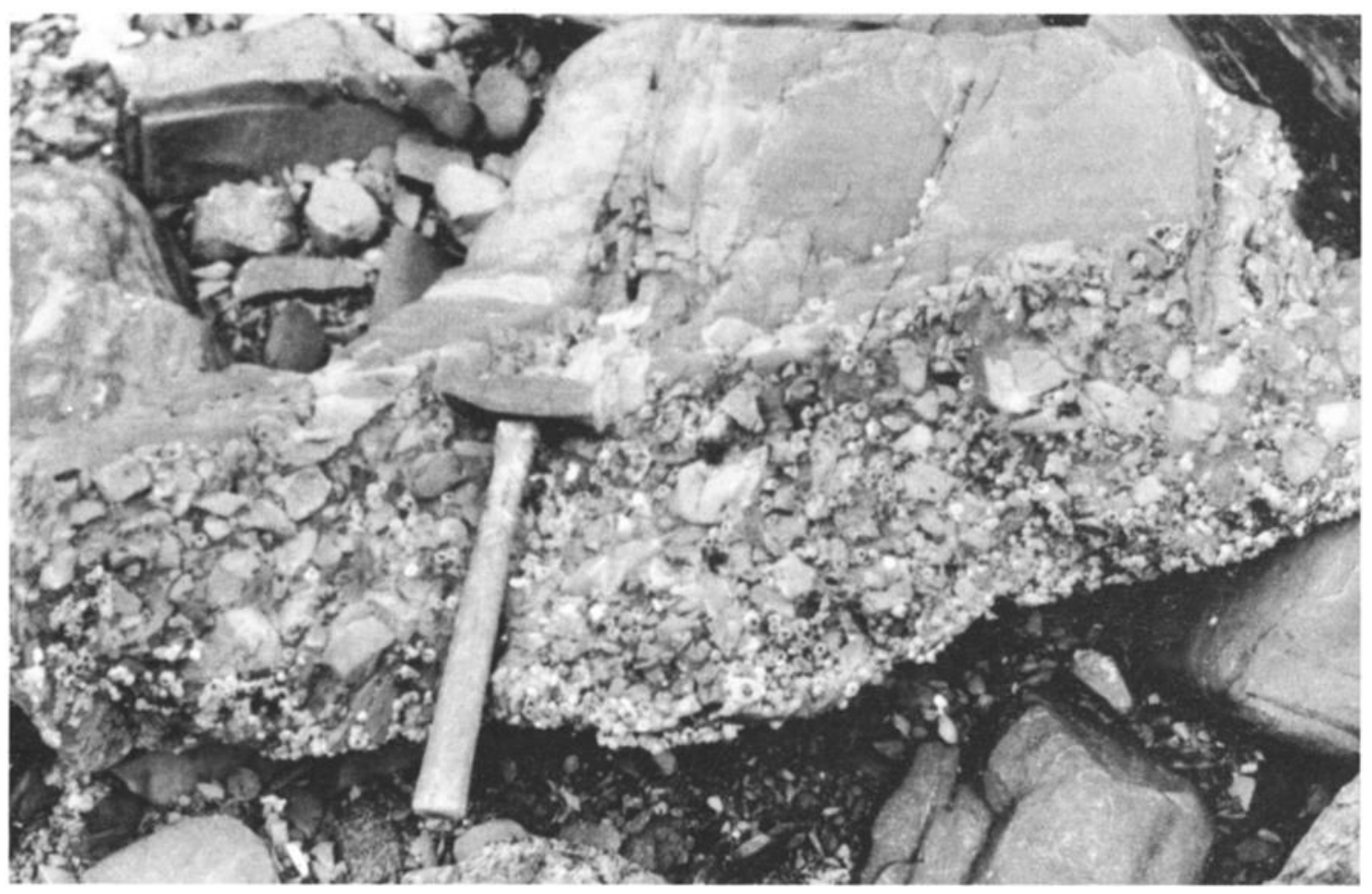

Fig. 4. Deformed basal conglomerate of the lower member of the Gravina sequence on northwestem Annette Island (Figure 2), with clasts from the underlying Triassic Hyd Group of the Alexander terrane. 
the lower unit. On the northwest shore of Annette Island, massive augite porphyry intrudes banded carbonaceous limestone, laminated felsic tuff, and limestone of the Alexander terrane.

Plutonic rocks. Structurally concordant tabular bodies of hypabyssal diorite intrude lower unit Gravina rocks. The diorite is texturally diverse and displays relict porphyritic, ophitic, and granular textures. The contact between the diorite and enclosing volcanic rocks is compositionally and texturally gradational and lacks a well-defined contact aureole. Attempts to extract zircon for $\mathrm{U}-\mathrm{Pb}$ isotopic analyses from varied textured diorite were unsuccessful.

Age. The age of the lower unit is poorly constrained and is based upon fossil ages reported by Chapin [1918], Berg et al. [1972], and Berg [1973]. Poorly preserved Buchia rugosa is present in argillite on southem Gravina Island, indicating a Late Jurassic age (Kimmeridgian) (Figure 3). Abundant belemnites ( $C$ ylindroteuthis) which range in age from Middle to Late Jurassic [Berg, 1973] occur on Blank Inlet on southern Gravina Island. Large (up to $20 \mathrm{~cm}$ in diameter) pelecypods (Entolium), which range in age from Middle Triassic to Early Cretaceous, are also present from Blank Inlet and Blank Island, [Berg, 1973]. The lower age limit is post-Upper Triassic, the age of the youngest fossils in the underlying Alexander terrane. In summary, available fossil age data indicate a Late Jurassic age for at least part of the lower unit of the Gravina sequence [Berg, 1973; Berg and Cruz, 1982].

Geochemistry. A critical question concerning the Gravina sequence volcanics is the identification of their paleotectonic environment. For mafic volcanic rocks which have undergone low grade metamorphism, two useful methods classify and discriminate magmas erupted in different tectonic settings: (1) concentrations of trace elements such as $\mathrm{Ti}, \mathrm{Zr}, \mathrm{Y}, \mathrm{Cr}$, and $\mathrm{Nb}$ and (2) concentrations of rare earth elements (REE) in the lavas and dikes [Pearce and Cann, 1973; Winchester and Floyd, 1973; Garcia, 1978; Gill, 1981; Pearce, 1982, 1983; Pearce et al., 1984; Thompson, 1982]. The criteria used to distinguish tectonic affinities of magmas are derived from empirically determined values from a variety of modern plate tectonic settings [Pearce, 1982, 1983; Pearce and Norry, 1979]. Trace elements that are relatively immobile during seafloor alteration and greenschist facies metamorphism are used [Cann, 1970; Humphris and Thompson, 1978]. Rare earth, major, and trace element analyses of lavas and dikes from the Gravina sequence are given in Tables 1 and 2, and the data are plotted on both trace element discrimination diagrams (Figure 5) and on a rare element discrimination diagrams (Figure 6), according to the conventions suggested by Thompson [1982], and Pearce [1982].

These discrimination diagrams suggest that most of the Gravina sequence lavas and dikes closely resemble modem island arc tholeiites (IAT) (Figures $5 a$ and $5 b$ ). $\mathrm{Ti} / \mathrm{Zr}$ ratios of the Gravina volcanics fall within the arc tholeiite field; the only exception is sample 85CR206, which falls in the continental arc basalt field. On a $\mathrm{Cr} / \mathrm{Y}$ plot (Figure $5 b$ ) the data plot either in the low $Y$ part of the arc tholeiite field or in the high $\mathrm{Y}$ part of the MORB field. $\mathrm{Ti} / \mathrm{Zr}$ ratios are low and plot within the IAT and continental arc basalt field or arc tholeiiteMORB overlap fields; however, these low $\mathrm{TiO}_{2}$ and $\mathrm{Zr}$ values are not typically seen in MORB [Pearce and Cann, 1973]. When $\mathrm{Nb} / \mathrm{Y}$ is plotted against $\mathrm{Zr} / \mathrm{TiO}_{2}$, all of the values fall within the andesite/basalt and overlap with the subalkaline basalt fields. Typically, these samples have low $\mathrm{Nb} / \mathrm{Y}$ and $\mathrm{Zr} / \mathrm{TiO}_{2}$ ratios. $\mathrm{REE}$ and incompatible trace element data show typical patterns for basalts erupted in a oceanic island arc setting (Figure 6). These analyses indicated that they are generally similar to the average island arc tholeiite basalt [Pearce, 1982, 1983; Thompson, 1982] and are products of subduction-related magmatism. The Gravina volcanic rocks have low REE abundances and minor LREE (light rare earth elements) enrichment (Figure 6c), which is characteristic of modem arc tholeiite suites [Gill, 1981]. Low $\mathrm{TiO}_{2}$ and $\mathrm{Cr}$ contents are consistent with this interpretation.

Trace elements also provide information on both the source and subsequent differentiation history of magmas. There is a characteristic trace element signature for volcanic rocks erupted at convergent plate margins; in particular, source regions are typically enriched relative to $\mathrm{REE}$ in both $\mathrm{K}$ group and Th group trace elements and depleted in $\mathrm{Ti}$ group trace elements [Gill, 1981]. Ratios of highly incompatible trace elements reflect source composition because they do not change during melting or fractionation. The Gravina sequence mafic lavas are enriched relative to MORB in $\mathrm{Ba}, \mathrm{Sr}, \mathrm{K}, \mathrm{Rb}$, and Th (Figure 6); these patterns may be attributed to a subducted sedimentary component [e.g., Kay, 1980]; however, this enrichment can also record local variations of arc basement [Moorbath and Hildreth, 1988]. Alternately, seafloor and subsequent regional metamorphism may have affected these values. A subducted-slab source for this enrichment is unlikely, because of the absence of negative Eu and $\mathrm{Ce}$ anomalies. The lack of Eu and $\mathrm{Ce}$ anomalies is thought to reflect the relative absence of a sedimentary contribution to the magma source [McLennan and Taylor, 1981; White and Dupré, 1986]. The mafic rocks are enriched in LIL (large ion

TABLE 1. Major and Minor Element Analyses of Gravina Sequence Volcanics

\begin{tabular}{|c|c|c|c|c|c|c|c|c|c|}
\hline \multicolumn{10}{|c|}{ Sample } \\
\hline & 84JRa & 84JRb & 85CR104a & 85CR206 & $85 C R 220 a$ & $85 C R 221$ & $85 C R 227$ & 87CR31 & 87 CR 38 \\
\hline$\overline{\mathrm{SiO}_{2}}$ & 49.40 & 52.10 & 47.90 & 46.90 & 48.70 & 48.44 & 49.40 & 47.90 & 47.60 \\
\hline $\mathrm{Al}_{2} \mathrm{O}_{3}$ & 16.90 & 17.70 & 16.50 & 18.20 & 10.60 & 18.50 & 18.50 & 12.50 & 13.20 \\
\hline $\mathrm{Fe}_{2} \mathrm{O}_{3}$ & 8.85 & 8.59 & 11.10 & 11.80 & 9.73 & 10.60 & 9.41 & 14.10 & 11.20 \\
\hline $\mathrm{MgO}$ & 6.39 & 5.88 & 6.55 & 5.92 & 12.10 & 4.85 & 5.08 & 8.91 & 10.30 \\
\hline $\mathrm{CaO}$ & 9.49 & 9.03 & 12.90 & 3.86 & 11.40 & 10.50 & 12.00 & 11.00 & 9.81 \\
\hline $\mathrm{K}_{\mathbf{2}} \mathrm{O}$ & 0.66 & 0.91 & 0.83 & 0.51 & 0.61 & 0.86 & 1.20 & 0.24 & 0.15 \\
\hline $\mathrm{Na}_{2} \mathrm{O}$ & 3.19 & 3.40 & 1.73 & 4.80 & 2.91 & 2.91 & 2.00 & 1.29 & 3.12 \\
\hline $\mathrm{TiO}_{2}$ & 0.53 & 0.50 & 0.69 & 1.15 & 0.65 & 0.56 & 0.60 & 1.00 & 0.15 \\
\hline $\mathrm{P}_{2} \mathrm{O}_{5}$ & 0.09 & 0.09 & 0.11 & 0.49 & 0.21 & 0.12 & 0.12 & 0.28 & 0.83 \\
\hline $\mathrm{MnO}$ & 0.19 & 0.19 & 0.21 & 0.19 & 0.15 & 0.19 & 0.15 & 0.19 & 0.28 \\
\hline
\end{tabular}

All analyses determined by Energy Dispersive-X-Ray Diffraction; analysts: J. Taggan, A. Bantel, and D. Siems. 


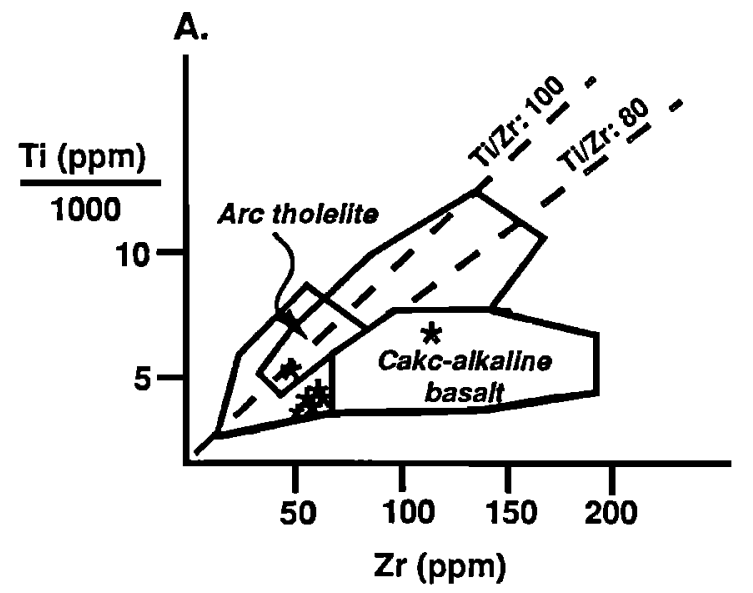

B.
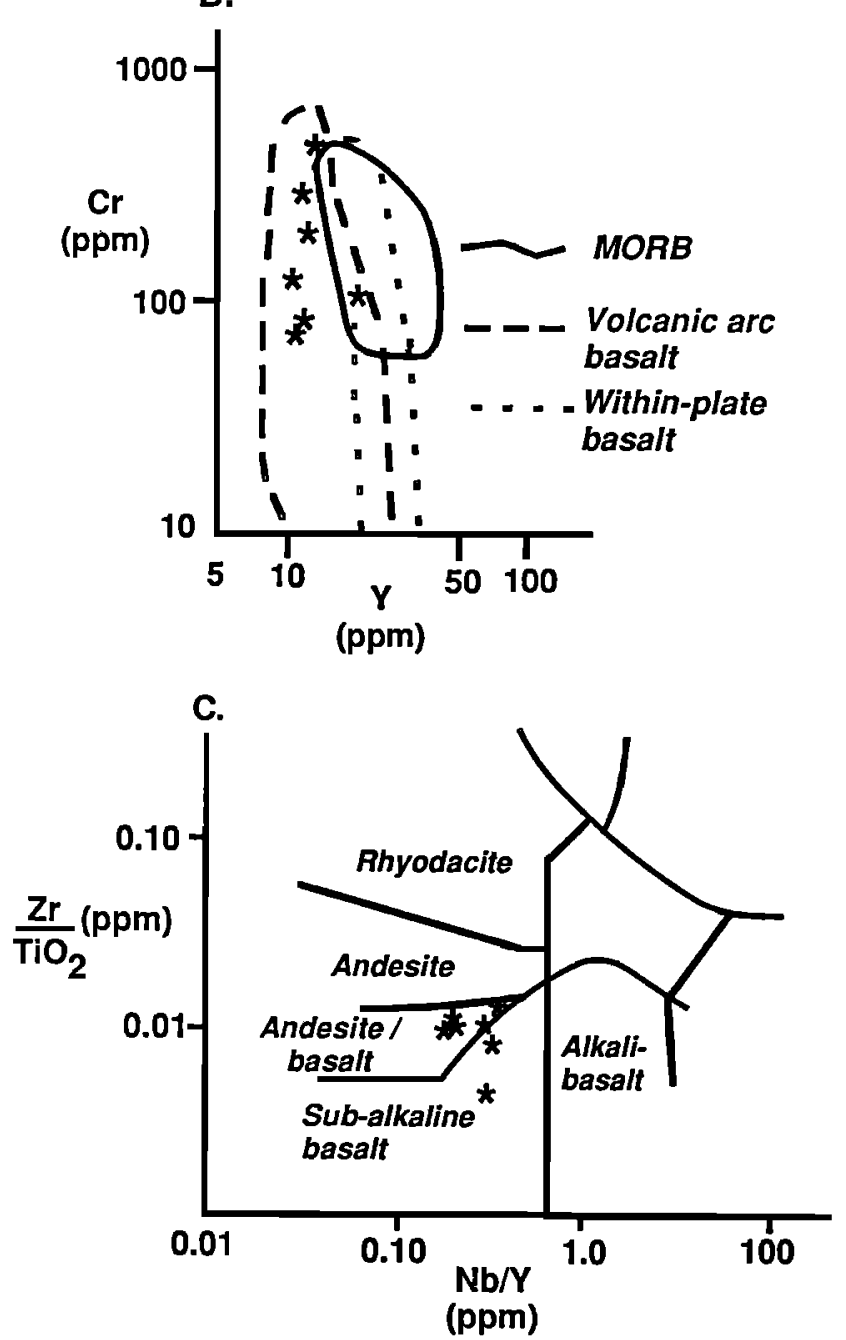

Figure 5. Trace-element discrimination diagrams showing data from Gravina sequence metabasalts. A) $\mathrm{Ti} / \mathrm{Zr}$ discrimination diagram of Pearce and Cann [1973]; B) $\mathrm{Cr} / \mathrm{Y}$ discrimination diagram of Pearce [1982]; $\mathrm{Zr} / \mathrm{TiO}{ }_{2}$ vs $\mathrm{Nb} / \mathrm{Y}$ discrimination diagram of Winchester and Floyd [1977].

lithophile) elements relative to MORB and have high $\mathrm{Ba} / \mathrm{Ta}$ ratios (>24, except 87CR206) which indicate excess LIL to light rare earth (LRE) elements relative to MORB. High $\mathrm{Ba} / \mathrm{Ta}$ ratios are common in volcanic arcs and are representative of
low-K island arc tholeiite magmas [Gill, 1981]. High $\mathrm{Ba} / \mathrm{La}$ and $\mathrm{Ba} / \mathrm{Ta}$ ratios, moderate $\mathrm{La} / \mathrm{Ta}$ ratios, and moderate LIL elements contents (relative to high field strength and LRE elements) are also characteristic of the Gravina sequence mafic rocks (Table 2). These values suggest that the Gravina basaltic magmas were controlled by the underlying mantle wedge and locally influenced by its ensimatic arc basement.

Based upon trace element abundances for $\mathrm{Cr}, \mathrm{Zr}, \mathrm{Ti}$, multi element and REE patterns, and combined with the presence of significant amounts of pyroclastic volcanic rocks and interbedded turbidites, we interpret the lower unit Gravina sequence volcanics as products of a oceanic volcanic arc complex. This interpretation is consistent with the original suggestion of Berg et al. [1972] that the Gravina-Nutzotin belt formed in a magmatic arc setting. These compositions and geochemical variations are similar to immature island arcs of the western Pacific [Gill, 1981].

Depositional setting. The base of the lower unit of the Gravina sequence contains pebble to cobble conglomerates thought to have been derived from the underlying Triassic Hyd Group. Based upon the presence of laterally continuous, planar-laminated, normally graded sequences of argillite, calcareous argillite, and siltstone, and the lenticular beds of the predominantly matrix-supported conglomerate, the lowermost part of the Gravina sequence is interpreted as submarine turbidite deposits. Lenses of coarse-grained conglomerate represent associated channel-fill deposits. Proximity to the Alexander terrane is suggested by two lines of evidence: (1) the coarse-grained detritus in the turbidites was derived from the underlying Alexander terrane and (2) lower unit homblende-augite porphyry intrudes Upper Triassic rocks of the Alexander terrane on Annette Island. Homblende-augite porphyry dikes represent the subvolcanic feeder to the overlying volcanic rocks.

Large volumes of mafic to intermediate volcanic debris overlie the argillaceous turbidites. These volcanic rocks contain mostly coarse-grained pyroclastic deposits, phyric tuff, and massive flows. Monolithologic blocks in tuff breccia and blocky flows indicate little or no mixing of volcanogenic debris. The compositionally uniform crystal-rich mafic tuff matrix suggests that the deposits are a direct result of explosive eruptions. Locally, pillowed and massive flows overlie and are intercalated with argillaceous turbidites. Deeper structural levels are represented by the texturally varied diorite. The diorite is compositionally and texturally similar to the volcanic rocks, displays the same structural and metamorphic features, and lacks a well-defined contact aureole, substantiating the suggestion of Berg [1972] that the diorite and metavolcanic rocks are co genetic. The intrusion of hypabyssal diorite into the pyroclastic aprons probably caused sediment failure that resulted in volcanic slides, similar to geologic relations observed in Jurassic volcaniclastic sedimentary rocks on Cedros Island [Busby-Spera, 1988].

Sedimentary and igneous structures of the pyroclastic deposits and mafic lava flows indicate that both distal and proximal volcanic facies are present. Proximal lava flows are pillowed and unbroken, whereas distal positions are dominated by pillow breccia. The proximal pyroclastic deposits contain large, juvenile monolithologic blocks; accidental fragments are uncommon. Fine-grained crystal-rich tuff, lapilli-sized lithic tuff, and tuffaceous turbidites are more common in distal areas. Northern and western source areas for the volcaniclastic aprons are supported by stratigraphic and sedimentologic data. 
TABLE 2. Trace Element Analyses of Gravina Sequence Volcanics

\begin{tabular}{|c|c|c|c|c|c|c|c|}
\hline & & & & Sample & & & \\
\hline & 84JRa & 84JRb & 85CR104a & 85CR206 & $85 C R 220 a$ & 85CR221 & $85 C R 227$ \\
\hline $\mathrm{Ba}$ & 214.0 & 255.0 & 314.0 & 316.0 & 201.0 & 208.0 & 234.0 \\
\hline $\mathbf{R} \mathbf{b}$ & 10.1 & 16.5 & 13.2 & 16.3 & 7.62 & 15.9 & 11.6 \\
\hline Th & 0.785 & 0.771 & 0.57 & 3.71 & 0.96 & 0.97 & 0.68 \\
\hline $\mathbf{K}$ & 5478.0 & 7554.0 & 6891.0 & 4234.0 & 5064.0 & 7143.0 & 9962.0 \\
\hline $\mathbf{N b}$ & $<10.0$ & $<10.0$ & $<10.0$ & $<10.0$ & $<10.0$ & $<10.0$ & $<10.0$ \\
\hline $\mathrm{Ta}$ & 0.201 & 0.203 & 0.0859 & 0.494 & 0.163 & 0.14 & 0.126 \\
\hline $\mathrm{La}$ & 4.94 & 4.88 & 4.62 & 20.90 & 8.50 & 6.16 & 5.08 \\
\hline Ln & 0.271 & 0.269 & 0.222 & 0.317 & 0.187 & 0.258 & 0.225 \\
\hline$\overline{C E}$ & 10.4 & 10.63 & 10.1 & 46.63 & 19.9 & 12.5 & 9.86 \\
\hline En & 0.652 & 0.707 & 0.751 & 1.77 & 0.970 & 0.704 & 0.625 \\
\hline $\mathrm{Sr}_{\mathbf{r}}$ & 500.0 & 480.0 & 370.0 & 620.0 & 300.0 & 490.0 & 350.0 \\
\hline Nd & 6.5 & 7.18 & 6.84 & 26.7 & 12.69 & 7.94 & 7.52 \\
\hline Sm & 1.93 & 2.00 & 2.18 & 6.52 & 3.17 & 2.14 & 1.94 \\
\hline $\mathbf{N i}$ & 50.7 & 47.5 & 28.1 & 31.5 & 116 & 26 & 20.0 \\
\hline $\mathrm{Cr}_{\mathrm{r}}$ & 209 & 124 & 50.8 & 30.1 & 622 & 14.7 & 14.3 \\
\hline $\mathbf{P}$ & 393.0 & 393.0 & 480.0 & 2138.0 & 916.0 & 524.0 & 524.0 \\
\hline Hf & 1.09 & 1.08 & 0.805 & 2.54 & 1.14 & 1.16 & 0.961 \\
\hline $\mathbf{T i}$ & 3177.0 & 2998.0 & 4136.6 .0 & 6894.0 & 3897.0 & 3357.0 & 3597.0 \\
\hline $\mathbf{U}$ & 0.302 & 0.385 & 0.271 & 1.49 & 0.427 & 0.557 & 0.343 \\
\hline $\mathbf{Y}$ & 12.0 & 12.0 & 10.0 & 20.0 & 12.0 & 12.0 & 10.0 \\
\hline $\mathrm{Yb}$ & 1.77 & 1.81 & 1.62 & 2.14 & 1.14 & 1.69 & 1.46 \\
\hline $\mathbf{Z}_{\mathbf{r}}$ & 55.0 & 55.0 & 40.0 & 110.0 & 55.0 & 60.0 & 45.0 \\
\hline $\mathrm{Ba} / \mathrm{La}$ & 43 & 52 & 68 & 15 & 24 & 34 & 46 \\
\hline $\mathrm{Ba} / \mathrm{Ta}$ & 1065 & 4256 & 3655 & 640 & 1233 & 1486 & 1857 \\
\hline $\mathrm{Ce} / \mathrm{Yb}$ & 5.9 & 5.9 & 6.2 & 21.8 & 17.4 & 7.3 & 6.7 \\
\hline $\mathrm{Hf} / \mathrm{Lu}$ & 4.0 & 4.0 & 3.6 & 8.0 & 6.0 & 4.5 & 4.3 \\
\hline Hff/Ta & 5.4 & 4.5 & 9.3 & 5.1 & 7.0 & 8.3 & 7.6 \\
\hline $\mathrm{La} / \mathrm{Sm}$ & 2.5 & 2.4 & 2.1 & 3.2 & 2.7 & 2.9 & 2.6 \\
\hline $\mathrm{La} / \mathrm{Ta}$ & 24 & 24 & 54 & 43 & 52 & 44 & 40 \\
\hline
\end{tabular}

Minor and rare earth elements abundances are given in parts per million. $R b, \mathrm{Nb}, \mathrm{Sr}, \mathrm{Y}$, and $\mathrm{Zr}$ were determined by Energy Dispersive, $\mathrm{X}$-Ray Fluorescence; other minor elements by Neutron Activation. Analysts: D. Fey, J. Budahn, T. Frost (trace elements) and S. Mac Pherson (wet chemistry).

The thickness and overall grain size of mafic pyroclastic deposits decrease to the south and east. There are no known coarse-grained pyroclastic rocks on the eastern and southern portions of the Gravina basin in the Ketchikan area. Vent plugs, represented by hypabyssal diorite of various textures, are present on the northern and western margin, which supports the idea of a northem and western source for the volcaniclastic sedimentary rocks. The widespread occurrence of mafic flows indicates that fissures must have been present throughout the basin.

A simple progradational depositional sequence emerges from facies relations within the lower unit. The basal unit was deposited as turbiditic flows with channel-fill sequences containing clasts derived from the underlying Alexander terrane. The turbidites are overlain by thick, submarine pyroclastic debris and lava flows. The predominance of pyroclastic deposits interbedded with massive flows and tuff and argillaceous turbidites, together with the presence of cogenetic intrusives and trace element geochemistry, indicates a basinal volcanic arc setting for the lower part of the Gravina sequence. These basinal pyroclastic deposits were shed from the flanks of submarine stratovolcanos during Late Jurassic time. Hypabyssal intrusive rocks represent the intrusive equivalents of the lavas recognized within the section.

\section{Upper Unit}

Stratigraphy. The upper unit consists of poorly exposed siltstone, argillite, tuff, slate, and conglomerate. In the study area, this unit extends from the south on Annette Island to Cleveland Peninsula in the north (Figure 2). The best exposures are on southern Cleveland Peninsula, southwestern Revillagigedo Island and adjacent smaller islands. The lower contact of this unit is not exposed; however, locally it is inferred to unconformably overlie both the lower volcanic unit of the Gravina sequence and the Permian and Triassic Alava sequence (Figure 4). Cobble conglomerate locally unconformably overlies Alava strata; no evidence for faulting is present. The top of the section is not exposed and the highest observed levels are in fault contact with adjacent terranes.

The upper unit has an approximate structural thickness of $900 \mathrm{~m}$. The unit is readily distinguished from similar rock types in both the lower unit of the Gravina sequence and the Alava sequence by the predominance of argillaceous turbidites, the presence of interbedded pebble to cobble conglomerate interstratified with the turbidite deposits, and the lack of mafic metavolcanic rocks. Sedimentary structures are generally better preserved here than in the lower unit.

Lithologic units in the upper unit can be divided into two groups or facies: (1) argillaceous and tuffaceous turbidites and (2) pebble to cobble conglomerate. The argillaceous strata are characterized by very fine to fine-grained clastic beds which contain mostly dark grey, argillaceous siltstone, mudstone, and minor feldspathic sandstone and silty limestone. Sparse granules and pebbles are present within the argillaceous layers and are composed of very -fine grained felsic igneous clasts. Bedding is generally medium to thick $(20-80 \mathrm{~cm})$; however, 

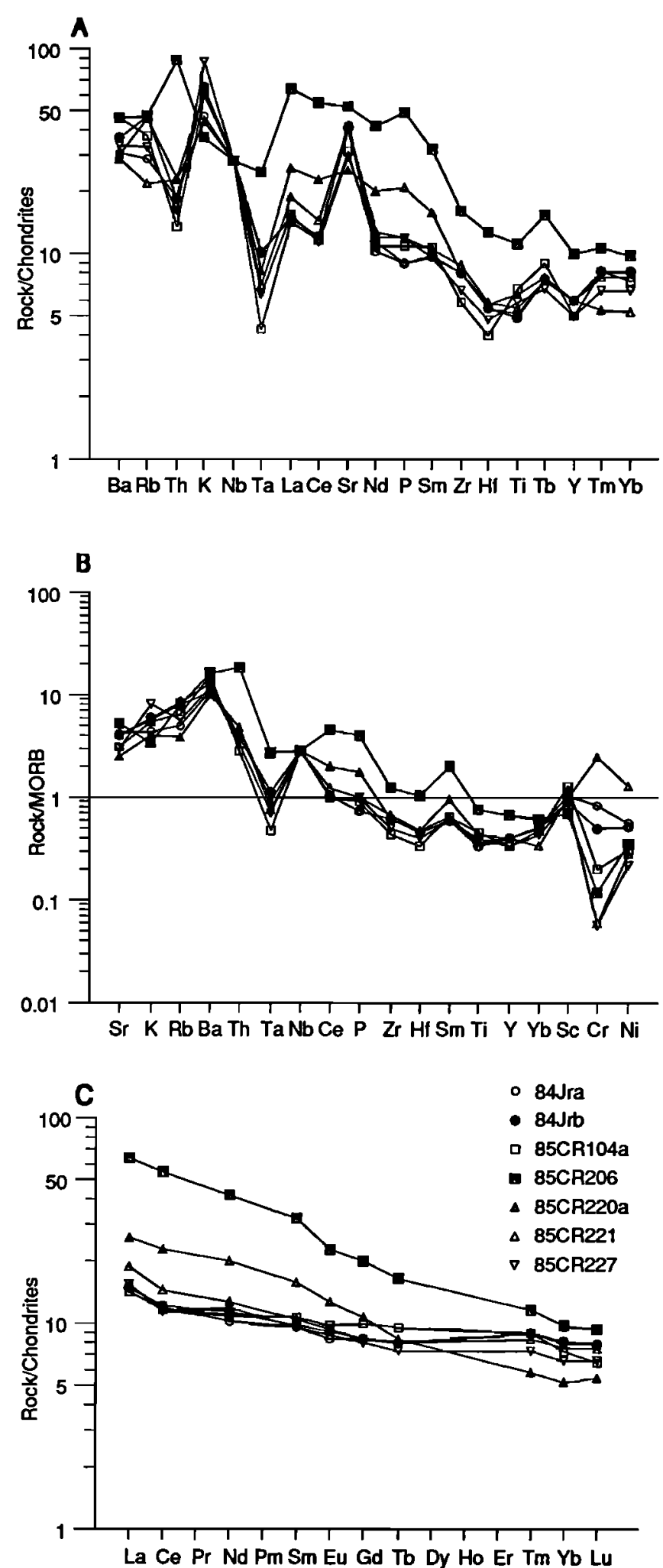

Fig. 6. Nomalized incompatible element pattems for the Gravina sequence metabasalts. a) Chondrite-normalized plot after Thompson [1982], b) MORB-nomalized plot after Pearce [1983], c) Chondritenormalized REE plot. All data normalized after Nakamura [1974]. Multi element plots generated by a computer program after Wheatley and Rock [1988].

massive beds are up to $2 \mathrm{~m}$ thick are present locally. Argillite rip-up clasts are common within the sandy layers. Graded bedding, plane-laminated sandy layers, and amalgamated beds are present locally (Figure 7). Other bedform structures are not recognized. The tuffaceous strata consist of very fine to finegrained, light gray to $\tan$ beds with very small crystals of feldspar and mafic minerals in a white mica-epidote-feldspar matrix.

Pebble and cobble conglomerate is interbedded with the argillaceous turbidites (Figure 8). Conglomerate beds occur in a distinctive mappable horizon up to $2 \mathrm{~m}$ thick exposed between southeastem Revillagigedo Island and southern Cleveland Peninsula and consisting of beds 0.5 to $2 \mathrm{~m}$ thick. Beds are commonly lenticular on an outcrop scale. The conglomerate overlies finely laminated argillite and siltstone and grades stratigraphically upwards into grey argillite that contains fewer coarse clasts (Figure 7). The conglomeratebearing horizon also contains thin layers of grey phyllite and siltstone with sparse granules of leucocratic fragments and argillite rip-up clasts. The conglomerate is matrix-supported, and clasts are usually less than $18 \mathrm{~cm}$ in diameter, averaging 3$8 \mathrm{~cm}$. The matrix is argillaceous. On Revillagigedo and adjacent islands, boulders up to $40 \mathrm{~cm}$ in diameter occur. The clasts are mostly flattened as the result of younger deformation (Figure 8) and consist of fine- to coarse-grained granodiorite, quartz diorite and leucocratic diorite, volcanic porphyry, argillite, and minor marble and vein quartz material. The matrix is fine-grained argillite containing quartz, albite, biotite, epidote, calcite, and white mica.

Provenance and $\mathrm{U}-\mathrm{Pb}$ isotopic data. The rock types of clasts in the pebble to cobble conglomerates were counted in the field (Table 3) and have been plotted according to major constituents on ternary diagrams (Figure 9). The conglomerate units contain mostly volcanic and plutonic lithic clasts, with relatively few sedimentary lithic clasts. Mixing of these two rock types within the conglomerate suggests that they were derived from a composite volcanic-plutonic source. The presence of plutonic and lesser volcanic clasts suggests deposition near an uplifted region comprised of both its volcanic cover and plutonic substrate.

Ages of granodiorite and quartz diorite clasts within the pebble to cobble conglomerate have been determined using U$\mathrm{Pb}$ zircon methods (Tables 4 and 5). Zircon separates were prepared by standard mineral separation techniques. Isotopic data were determined on a $35 \mathrm{~cm} \mathrm{VG} 90^{\circ}$ extended geometry sector multicollector and on a $30.48 \mathrm{~cm} 60^{\circ}$ Lunatic IV mass spectrometer at Caltech. Lead was loaded with $\mathrm{H}_{3} \mathrm{PO}_{4}$ acidsilica gel [Cameron et al., 1969], and uranium was loaded with $\mathrm{H}_{3} \mathrm{PO}_{4}$ acid and graphite. Uranium and lead concentrations were determined on solution aliquots from each sample by isotope dilution using a mixed 205Pb-230Th-235U spike.

Seven fractions from four granodiorite and quartz diorite clasts from Gnat Cove and Back Island were analyzed (Tables 4 and 5). The zircon isotopic systematics of the Gnat Cove samples (84JR28 C-1 and C-3; Table 5) are relatively simple and are interpreted as crystallization ages. These samples yield concordant ages of $154 \mathrm{Ma}$ and $158 \mathrm{Ma}$ (Figure 10). The zircon isotopic data for clast $\mathrm{C}-3$ are slightly discordant. The igneous age interpretation for this sample is highly dependent on the discordance mechanism chosen to explain the data. The limited zircon yield from the clast prohibit an in-depth analysis of this question. Broad age bounds are assigned as 172 to $154 \mathrm{Ma}$ (Figure 10), based on possible minor disturbance at a level which would permit the $>62 \mu \mathrm{m}$ fraction to retain its internal concordance or, alternatively, minor inheritance which would disperse the $>62 \mu \mathrm{m}$ fraction off of concordia from the internally concordant fraction. Thus we interpret the age as $154 \mathrm{Ma}$. The igneous clast from Back 


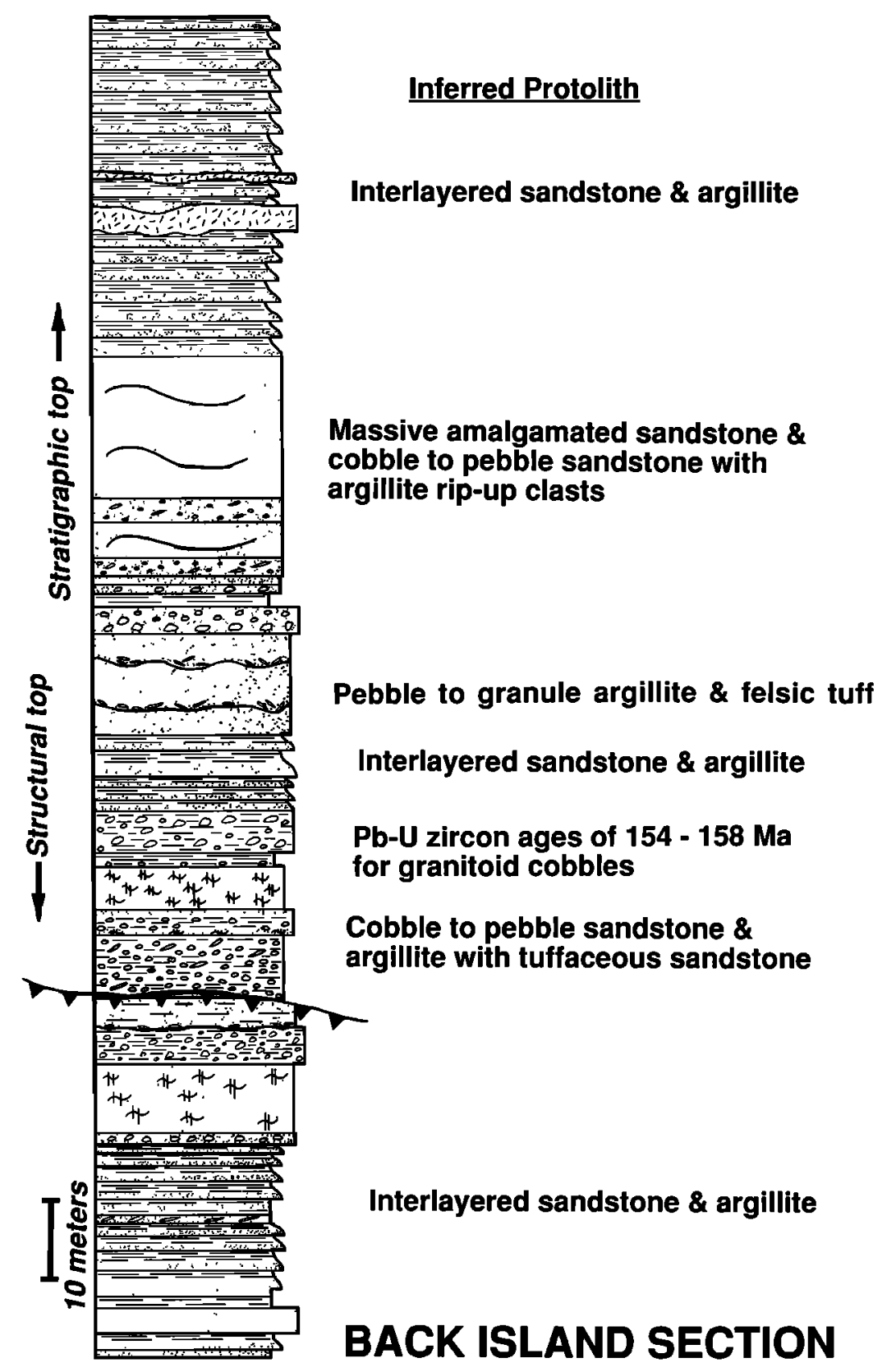

Fig. 7. Measured structural-straligraphic section of part of the upper member of the Gravina sequence on Back Island.

Island (Figure 2) yields an intemally concordant age of $157 \mathrm{Ma}$ (Figure 10). The close agreement between the $\mathrm{U}-\mathrm{Pb}$ ages of all four samples indicates that they represent Late Jurassic crystallization ages for the clasts and suggests a homogeneous or localized source terrane. Clasts from localities that occur over $35 \mathrm{~km}$ along strike have common lithologic and $\mathrm{U}-\mathrm{Pb}$ zircon systematics.

Several possible origins for the coarse plutonic detritus exist. The clasts were previously thought to have been derived from early Paleozoic plutons that are part of the Alexander terrane [Berg et al., 1988], but this possibility is ruled out by Jurassic U-Pb age data. A likely possibility is that the coarsegrained detritus was derived from an uplifted and dissected part of the Gravina arc and its underlying basement complex. The ages of the clasts are similar to those of Late Jurassic fossils found in the lower unit of the Gravina sequence [Harland et al.,
1982]; however, intrusive bodies of similar age have yet to be found in the lower unit or its substrate. Despite the lack of dated intrusive rocks in the lower unit, the lower unit does contain rock types compositionally similar to some of the plutonic clasts that have been interpreted as cogenetic with the volcanic section, as discussed above. Furthermore, since Gravina overlap strata and its basement were structurally imbricated during mid-Cretaceous time, much of the arc is now concealed beneath thrust sheets.

Another possibility is that the granitic debris may have been derived from a displaced arc terrane that has been removed by strike-slip faulting. It has long been recognized that major strike-slip faulting has affected the northwestern Cordillera [Gabrielse, 1985; Oldow et al., 1989]. Both southern and northern source terranes exist which may have provided detritus for the upper unit conglomerates. To the south, in 


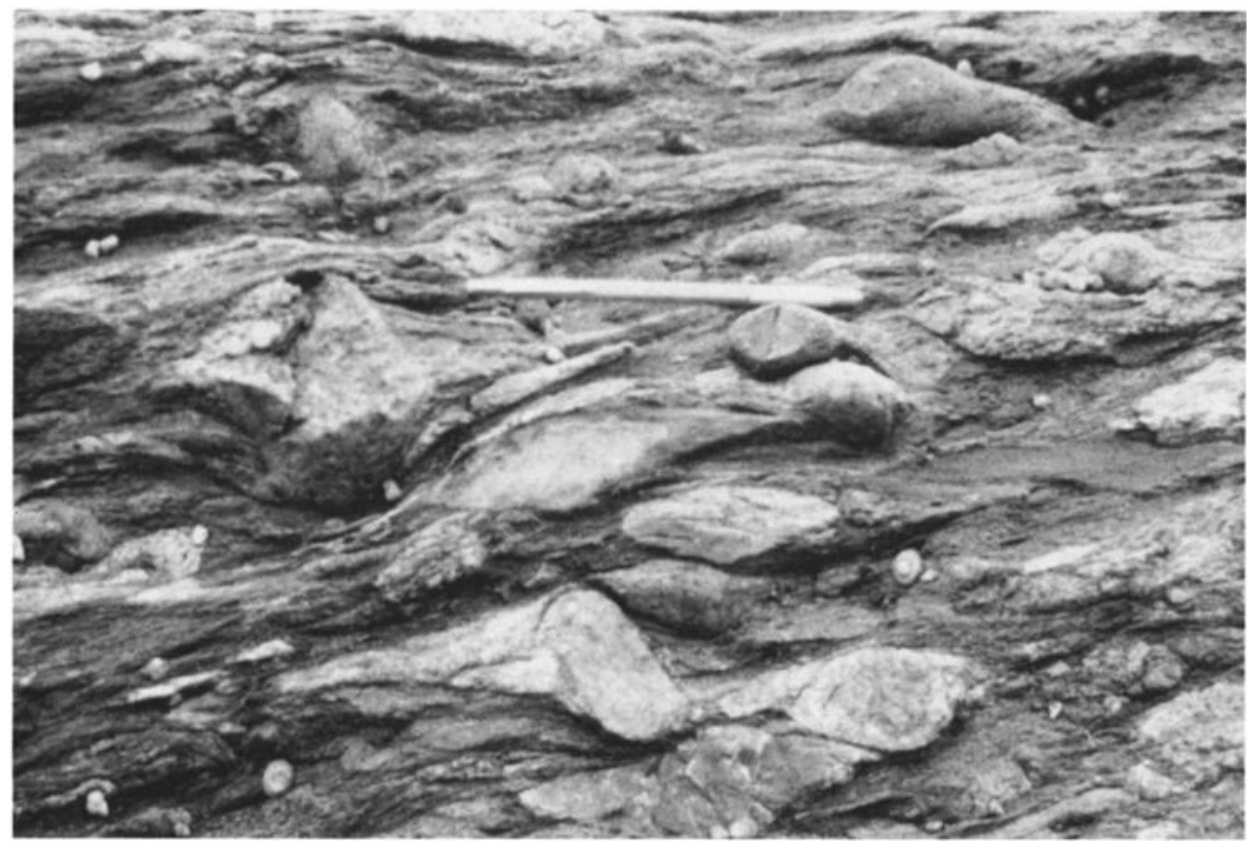

Fig. 8. Highly deformed channel-fill conglomerate of the upper member of the Gravina sequence on Betton Island. Plutonic clasts in the conglomerate yield U-Pb zircon ages of $154-158 \mathrm{Ma}$. The largest clast in the photograph is approximately $45 \mathrm{~cm}$ in diameter; clasts at Gnat Cove and Back Island are locally over $60 \mathrm{~cm}$ in diameter.

northwestern British Columbia, Late Jurassic igneous activity has been recognized recently within the Coast Plutonic Complex [Armstrong, 1988; Van der Heyden, 1989a]. Although many of these plutons display internal discordance, zircon from quartz diorite and granodiorite plutons yield crystallization ages from $154 \mathrm{Ma}$ to $158 \mathrm{Ma}$ [Van der Heyden, $1989 b$ ]. For this Late Jurassic plutonic suite to have provided the clastic detritus to the upper unit of the Gravina sequence, $150 \mathrm{~km}$ of post-Late Jurassic sinistral strike-slip displacement is required along inferred faults within the western boundary of the Gravina sequence. Strike-slip faults and associated fabrics of this age in southeastern Alaska and western British Columbia are lacking, and this hypothesis is difficult to test since critical contacts might lie underwater beneath Dixon Entrance or within the younger Coast Plutonic Complex on the mainland.

Altematively, Late Jurassic metaplutonic rocks in the eastern Chugach and St. Elias mountains, exposed to the north, may represent the source terrane for the upper unit igneous clasts. These metaplutonic rocks extend southeastward toward Chichagof Island in southeastern Alaska and are part of the Tonsina-Chichagof belt of Hudson [1983] and the Chilkat-Chichagof belt of Brew and Morrell [1983]. The belt consists of foliated hornblende quartz diorite, tonalite and granodionite. Age relations for much of the belt are poorly known; however, hornblende K/Ar cooling ages for these plutons range between $143 \mathrm{Ma}$ and $170 \mathrm{Ma}$, which suggests a regionally extensive Late Jurassic magmatic belt in southwestern Yukon and southeastern Alaska [Dodds and Campbell, 1988; Grantz et al., 1966; Loney et al., 1973; Karl et al., 1987]. U-Pb zircon ages from tonalite in the Chitina Valley region, are $153 \pm 4 \mathrm{Ma}$ [Plafker et al., 1989a]. Plafker et al. [1989a] cite evidence for offset of the early Mesozoic Talkeetna arc, truncation of the Chitina Valley plutons, and large-scale sub horizontal ductile shear along the truncated margin of Wrangellia as compatible with Late Jurassic to Early Cretaceous sinistral strike-slip motion of $600-1000 \mathrm{~km}$ in southeastern Alaska. A change in relative plate motions between the North American and Farallon plates [May and Butler, 1986] coincides with the initiation of sinistral strikeslip faulting. The inferred fault contact in southeast Alaska lies between Wrangellia and the Alexander terrane (Figure 1).

TABLE 3. Pebble and cobble counts, upper member of the Gravina sequence, southem southeastem Alaska

\begin{tabular}{lccccccc}
\hline & \multicolumn{6}{c}{ Occurrence (Percent of clasts randomly encountered) } \\
\cline { 2 - 8 } Area Sampled & $N$ & Li & Lv & Lvi & Ls & Lq & Lsa \\
\hline Cove & 102 & 98 & - & 98 & 2 & - & 2 \\
South Hume Island & 102 & 96 & - & 96 & 2 & 2 & 2 \\
Betton Island & 269 & 63 & 27 & 90 & 7.3 & 2 & 7.3 \\
Back Island & 102 & 47 & 34 & 81 & 16 & 3 & 16 \\
Gin Point & 105 & 87 & - & 87 & 11 & 2 & 11 \\
Guckers Cabin & 109 & 60 & - & 60 & 34 & 6 & 34 \\
\hline
\end{tabular}

$N$ is number of clasts counted, $\mathrm{Li}$ is lithic plutonicl; $\mathrm{Lv}$ is lithic volcanic; $\mathrm{Lvi}$ is total of $\mathrm{Li}$ and $\mathrm{Lv}$; $\mathrm{Ls}$ is argillite and marble; Lq is quartzite and quartz vein; Lsu is undifferentiated sedimentary rocks. 


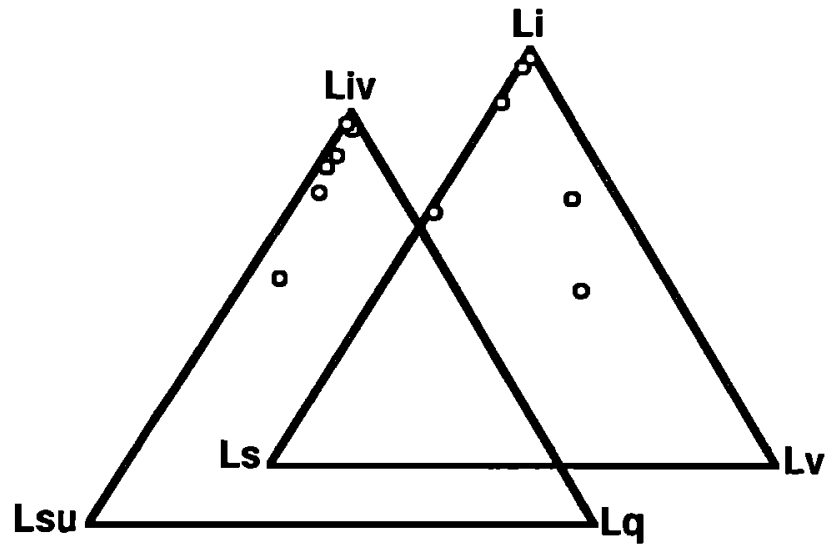

Fig.9. Composition of pebble and cobble populations from conglomerate within the upper member of the Gravina sequence, Lsu, lithic sedimentary undifferentiated; Liv, lithic volcanic and plutonic; $\mathrm{Li}$, lithic plutonic; Lv, lithic volcanic, Lq, lithic vein quartz and quartzile.

If these plutons are the source for the upper unit clasts, approximately $450 \mathrm{~km}$ of sinistral strike-slip offset is required along inferred faults located within or west of the Gravina arc strata (Figure 1). No such faults or associated fabrics in postJurassic strata, however, have been recognized in the region.

Therefore the three possible source terranes for the plutonic cobbles detritus include: (1) uplifted and dissected parts of the Gravina arc; (2) Late Jurassic plutonic rocks exposed to the south in northwestern British Columbia; and (3) Late Jurassic plutonic rocks exposed to the north in the eastern Chugach and St. Elias mountains. The second possibility is unlikely, as no offsets exist across hypothesized faults beneath Clarence Strait. Late Jurassic to Early Cretaceous sinistral strike-slip removal of the deeper portions of the arc and in situ structural burial of the plutonic source terrane are both plausible scenarios.

Age. No fossils have been found within the upper unit of the Gravina sequence in southern southeastern Alaska; thus, its $F$ depositional age is poorly constrained. The Late Jurassic provenance ages for granitic clasts provide a maximum age for deposition. Locally, the upper unit depositionally overlies the Upper Jurassic and Lower Cretaceous arc strata of the lower unit, which suggests a post-Early Cretaceous age; however, no primary fossil ages have been obtained from this part of the Gravina sequence.

North of the study area (Figure 1), on Etolin Island, ammonites (Arcthoplites belli and grantziceras sp.) of early Albian age are present in interbedded argillite, tuff, and volcanic breccia [Berg et al., 1972]. Based on similarities in lithology and stratigraphic position, the lower Albian strata on Etolin Island probably correlate with the upper unit of the Gravina sequence. Similar ammonites also occur in lower Albian strata of the Wrangell Mountains to the north [Imlay, 1960; Jones, 1967]. Based on geologic relations and sparse fossil data, an early Albian age is inferred for the upper unit clastic and tuffaceous strata.

Depositional setting. The upper unit of the Gravina sequence contains epiclastic and tuffaceous turbidites which were deposited in a submarine fan setting. The turbidites werc deposited on a composite basement consisting of the Alava sequence, the Alexander terrane, and the lower volcanic unit of the Gravina sequence. Large volumes of epiclastic debris were shed off the flanks of dissected volcanic centers in Early

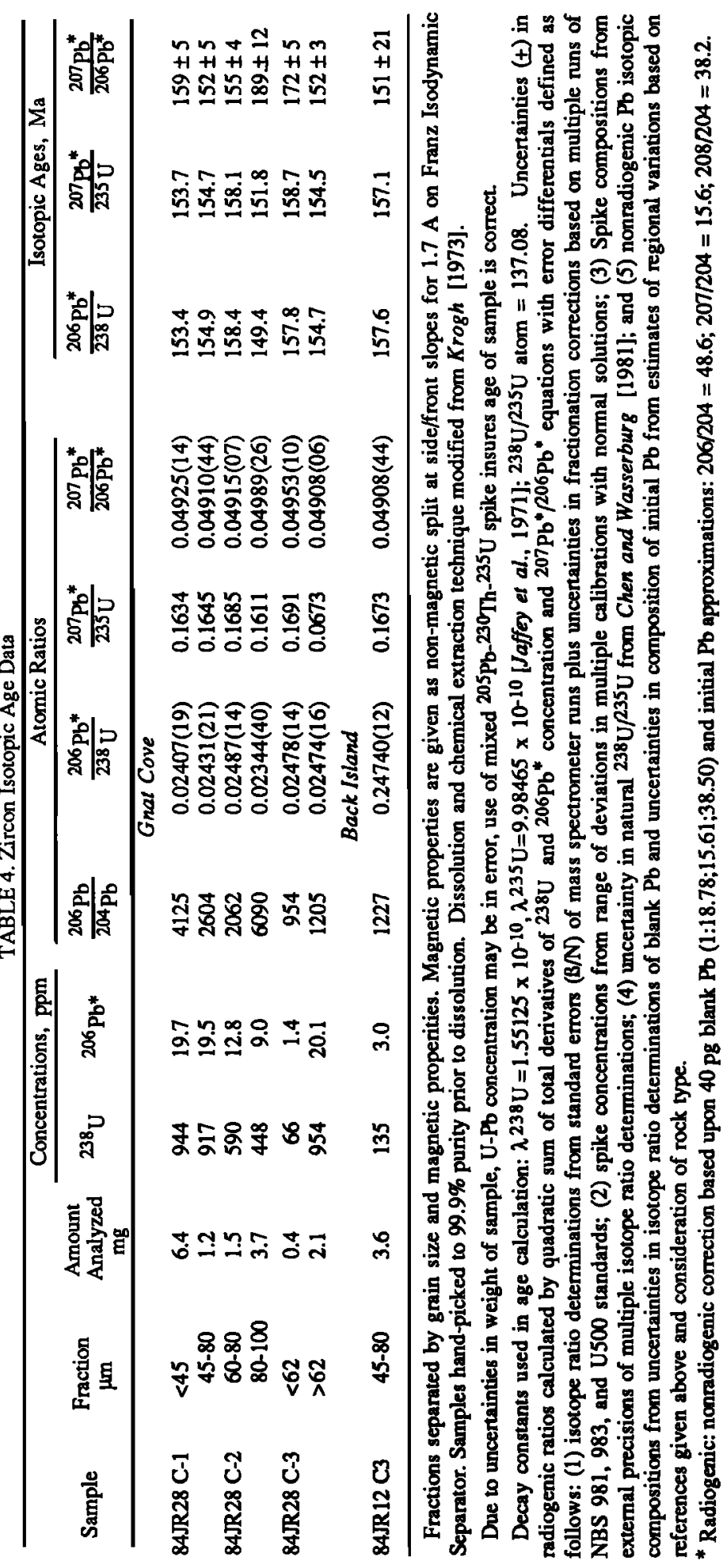


TABLE 5. U-Pb Geochronologic Sample Locations From the Ketchikan Area and Descriptions of Clasts from the Epiclatic Member of the Gravina Sequence

\begin{tabular}{|c|c|c|c|c|}
\hline Sample & Latitude & Longitude & Lithology & Zircon Properties \\
\hline \multicolumn{5}{|l|}{ 88JR28 } \\
\hline C-1 & $\mathrm{N} 55^{\circ} 22^{\prime} 50^{\prime \prime}$ & $131^{\circ} 19^{\prime} 24^{\prime \prime}$ & $\begin{array}{l}\text { Slighlly altered, nonfoliated } \\
\text { granodiorite }\end{array}$ & $\begin{array}{l}\text { 2:1 to 3:1; Sub=An>Eu; irregular shapes; } \\
\text { colorless, grey-tint; inclusions common }\end{array}$ \\
\hline C-2 & $\mathrm{N} 55^{\circ} 22^{\prime} 50^{\prime \prime}$ & $131^{\circ} 19^{\prime} 24^{\prime \prime}$ & $\begin{array}{l}\text { Slightly altered, nonfoliated } \\
\text { medium-grained biotite } \\
\text { granodiorite }\end{array}$ & $\begin{array}{l}\text { 2:1 to 3:1; Sub>Eu>An; irregular shapes; } \\
\text { colorless, grey-tint; inclusions common in } \\
\text { some grains }\end{array}$ \\
\hline C-3 & $\mathrm{N} 55^{\circ} 22^{\prime} 50^{\prime \prime}$ & $131^{\circ} 19^{\prime} 24^{\prime \prime}$ & $\begin{array}{l}\text { Slightly altered, nonfoliated fine- } \\
\text { grained leucograno-diorite }\end{array}$ & $\begin{array}{l}\text { 3:1; Sub=Eu>An; irregular shapes; colorless, } \\
\text { grey-tint; inclusions common in all grains }\end{array}$ \\
\hline \multicolumn{5}{|l|}{ 88JR12 } \\
\hline C-3 & $\mathrm{N} 55^{\circ} 32^{\prime} 9^{\prime \prime}$ & $131^{\circ} 45^{\prime} 15^{\prime \prime}$ & $\begin{array}{l}\text { Slightly altered, nonfoliated fine- } \\
\text { grained granodiorite }\end{array}$ & $\begin{array}{l}\text { 2:1, Sub>Eu >An; colorless, grey-tint nclusions } \\
\text { common in all grains }\end{array}$ \\
\hline
\end{tabular}

Abbreviations are Eu, euhedral; Sub, subhedral; An, anhedral. 2:1, length:width ratios of zircon grains. Color determined under reflected light. C-1, clast number.

Cretaceous time. Distal turbiditic strata locally interfingered with tuffaceous deposits suggesting ongoing volcanism. Although volumetrically much less abundant, conglomerates are present. Clasts in the conglomerate are commonly well rounded, indicating that detritus must have been reworked in a fluvial or beach environment prior to deposition by turbidity flows. Well-rounded cobbles suggest that parts of the arc were subaerially exposed and subject to erosion. The source of the dominantly granitoid Upper Jurassic clasts is not known. Epiclastic debris was derived from the intermediate to shallow levels of a dissected magmatic arc complex. The Late Jurassic

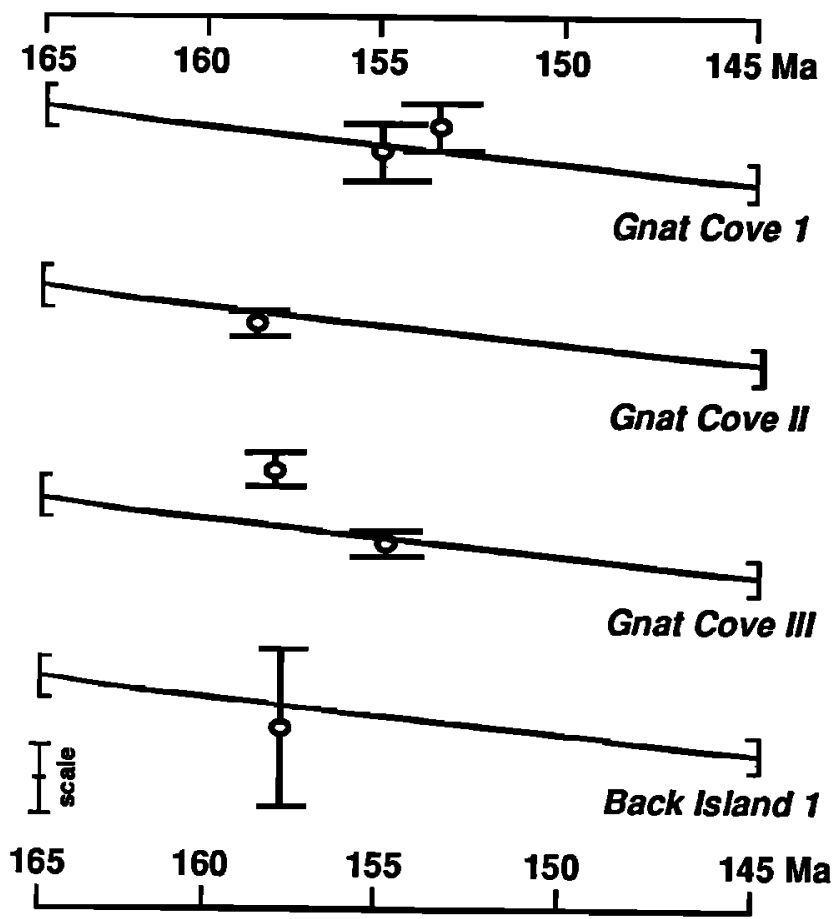

Fig. 10. Concordia plotted separately for each sample, with scale for ${ }^{20} \mathrm{~Pb} / 206 \mathrm{~Pb}$ ratio shown. Each segment contains data points and error bars for indicated samples of igneous clasts from Gnat Cove and Back Island. Bars at ends of concordia segments show uncertainty in $207 / 206 \mathrm{~Pb}$ values of concordia based on uncertainties in $238 \mathrm{U}$ and 235 U decay constants from Mattinson's [1987] treatment of Jaffey et al. [1971] data. Concordia diagram after Tera and Wasserburg [1972] Linear regression and errors in lower and upper intercepts are adapted from York [1969].
Gravina arc may have been the source terrane for the epiclastic debris and this interpretation is consistent with the presence of Upper Jurassic volcanic arc strata in the lower unit.

\section{DISCUSSION}

The Gravina sequence represents remnants of an oceanic island arc and its basinal sedimentary cover. The remnants include marine pyroclastic and volcaniclastic strata and basinal turbidites. The arc was constructed on a composite basement which consists of two elements, the Alexander terrane and the Taku terrane. The ensimatic nature of the arc basement is demonstrated by distinctive lithic components [Gehrels and Saleeby, 1987a,b], juvenile, mantle-derived magmas [Samson et al., 1989], a relatively small crustal volume of volcanic strata, the dominance of tholeiitic arc basalts, and paucity of felsic volcanic strata.

In southeast Alaska the oceanic island arc system was localized along the eastern margin of the Alexander terrane (Figure 1), where Upper Jurassic to Lower Cretaceous volcanic and basinal deposits accumulated on Upper Triassic and older strata of the Alexander terrane. Structures in the arc basement suggest that strike-slip [McClelland and Gehrels, 1990] and possible convergent displacements occurred during the early and middle Mesozoic. Rocks of the eastem part of the Alexander terrane were deformed and disrupted prior to the deposition of the Gravina sequence along the Duncan Canal Shear Zone in the Petersburg area [McClelland and Gehrels, 1990]. Similar stratigraphic relations may also be present on Chilkat Peninsula where Upper Triassic basalt, interpreted as a fragment of Wrangellia, underlies basinal turbidites that are tentatively correlated to the Gravina sequence [Plafker et al., $1989 b$ ]. Lower Mesozoic rocks of Wrangellia are thought to have formed in a rifted arc environment [Barker et al., 1989], analogous to the early Mesozoic history of the Alexander terrane.

The second basement component in the Ketchikan area consists of the Taku terrane (Alava and Kah Shakes sequences). Upper Paleozoic bioclastic limestone, massive to pillowed metabasaltic flows, and argillite of the Alava sequence are unconformably overlain by upper unit basinal turbidites and conglomerate of the Gravina sequence. The tectonic affinity of the Alava sequence is unclear; however, the primitive arc complex underlain by continent-derived clastic deposits may represent disrupted fragments of the late Paleozoic portion of 
the Yukon-Tanana and early Mesozoic part of the Stikine terranes [Rubin et al., 1990a; Rubin and Saleeby, 1991]. Thus the Gravina basement is composite, consisting of an ensimatic rifted arc (Alexander terrane), a primitive arc complex (Stikine terrane), and continent-derived slope and rise deposits (Yukon-Tanana terrane). The original dimensions of the arc system are obscured by late Mesozoic deformation [Crawford et al., 1987; Rubin et al., 1990b; G.E. Gehrels et al., Geologic and tectonic relations along the western flank of the Coast Mountains batholith between Cape Fanshaw and Taku Inlet, southeastern Alaska, submitted to Tectonics, 1991. hereinafter referred to as Gehrels et al., submitted manuscript, 1991; W.C. McClelland et al., The Gravina belt and YukonTanana terrane on central southeastern Alaska: Protolith relations of metamorphic rocks along the western flank of the Coast Mountains batholith, submitted to Journal of Geology, $1991 b]$ and fragmentary preservation.

The localization of oceanic island arcs along older rifted and structurally disrupted ensimatic basement fragments is well documented in modern island arc systems of the western Pacific (e.g., the Philippine Archipelago [Hawkins et al., 1985 and references therein]) and in ancient arc complexes of the North American Cordillera [Saleeby, 1983]. In the Philippine Islands the modern Mindanao arc nucleated above structurally disrupted ensimatic basement fragments that marked the collision between the central and eastern Mindanao belts [Hawkins et al., 1985; Karig, 1983]. The Mindanao composite arc basement includes crustal fragments that originated at the Pacific-Eurasian plate boundary [Karig, 1983], previously assembled by strike-slip and thrust faults. The similarity between the modern Mindanao arc with its composite basement and the Gravina sequence is striking.

The inception of arc volcanism recorded in the Gravina sequence probably began in the middle Late Jurassic, based on the oldest fossil ages on Gravina Island and to the north on Cape Fanshaw [Gehrels and McClelland, 1988]. Initially, basalt and basaltic andesite and pyroclastic flows of the lower unit accumulated on basinal sediments that unconformably overlie the Alexander terrane. The oldest basinal sedimentary rocks consist of rhythmically banded fine-grained turbidites interlayered with lenses of coarse detritus, derived from Triassic parts of the Alexander terrane. A Late Triassic through Middle Jurassic hiatus in deposition and the presence of basement-derived debris in Upper Jurassic strata suggest that the basement was locally subaerially exposed. Basement then subsided and accumulated fine-grained basinal sediments, massive mafic lavas, and pyroclastic debris of the lower unit. Progradation of pyroclastic aprons resulted in an upwardcoarsening sequence of volcaniclastic sedimentary rocks (Figure 3). Similar marine progradational sequences in volcaniclastic sediments have been recognized in the modern Mariana Island arc [Karig, 1971], in marginal basins of the southwestem Pacific Ocean [Klein, 1985], and as an important component in marginal basins [Karig and Moore, 1975]. Rapid buildup of pyroclastic aprons implies subsidence of the basin, which allows for the transport of coarse volcaniclastic debris into the basin. Alternatively, the progradational sequence may have resulted from migration of volcanism towards the basin. In either case, no simple pattern of volcanogenic sedimentation emerges from the available data.

A thick succession of epiclastic and tuffaceous turbidites blankets the lower volcanic sequence. The shift from volcanic to predominantly epiclastic deposition marks a fundamental change in the evolution of the Gravina basin. The turbidites were deposited on a varied substrate, including the Taku terrane (Alava sequence) and the lower volcanic unit of the Gravina sequence, indicating that the Alexander terrane and Taku terrane were amalgamated prior to the deposition of the upper unit. The presence of Late Jurassic granitoid cobbles in channel-fill deposits implies erosion and uplift of the older arc edifice, perhaps coeval with a change of relative plate motions during the latest Jurassic to earliest Cretaceous [Engebretsen et al., 1985]. Fine-grained epiclastic debris was also shed from the dissected arc. Interstratified tuffaceous turbidites record continued volcanism. Lack of quartz-rich terrigenous deposits indicates bathymetric or paleogeographic isolation from a continental source area.

Uplift and erosion of the older arc edifice and resulting influx of epiclastic debris probably occurred in the Early Cretaceous. The Gravina sequence is as young as Albian [Berg et al., 1972], and may be as young as Cenomanian (D. Brew, personal communication, 1987). Uplift and erosion of the basin may have been related to tectonic instability along western margin of the Alexander terrane during Aptian time. Mid-Cretaceous contractional deformation of the Gravina sequence has been described in southeast Alaska [Rubin et al., $1990 b$; Gehrels et al., submitted manuscript, 1991; McClelland et al., submitted manuscript, 1991a]. The uplift and erosion of adjacent parts of the Gravina belt may have marked the onset of mid-Cretaceous compression and collapse of the basinal sequence. Thick volumes of epiclastic debris record a fundamental change in the basin evolution and signals the onset of mid-Cretaceous orogenic activity.

On a regional scale, the timing of volcanism and epiclastic sedimentation in the Gravina sequence varies along strike. Farther to the north (Figure 1), in the Juneau region, epiclastic strata at the base of the Gravina sequence are overlain by metabasaltic lavas and pyroclastic rocks [Brew and Ford, 1985]. Based on regional stratigraphic relations the mafic volcanic strata may be as young as Early Cretaceous in age. Preliminary major element geochemical analyses suggest that the metabasalt formed in a rift environment [Ford and Brew, 1987]; however, a volcanic arc setting is also comparable with available data. Similar geologic relations are present in the enstern Alaska Range where Upper Jurassic to Lower Cretaceous volcanic and basinal strata form a thick and continuous section [Berg et al., 1972; Lowe et al., 1982; Richter, 1976]. The stratigraphically lowest rocks, consisting of Upper Jurassic shallow water marine sedimentary rocks overlain by turbidites and conglomerate, unconformably overlie Paleozoic and Mesozoic rocks of Wrangellia and contain coarse detritus derived from the underlying basement [Berg et al., 1972]. Neocomian arc-related volcanic strata of the overlying Chisana Formation consist of submarine and nonmarine mafic and intermediate flows, volcaniclastic rocks, and shallow marine argillite [Barker, 1987; Richter and Jones, 1973]. Thus the inception of volcanic activity in the eastern Alaska Range and in the Juneau area is perhaps younger than volcanic activity recorded in the Ketchikan area.

The deeper levels of the Upper Jurassic magmatic arc are exposed only locally, in the St. Elias Mountains of the Yukon and British Columbia, and possibly in Coast Range of northwestern British Columbia. Recent studies conducted in the Coast Ranges of western British Columbia have revealed a deeper level of exposure of the Upper Jurassic magmatic arc than in southern southeastern Alaska [Crawford et al., 1987; 
Hollister et al., 1987; Van der Heyden, 1989a; Woodsworth et al., 1983]. Here, Upper Jurassic plutons intrude the Alexander terrane and represent the roots of a magmatic arc [Armstrong, 1988; Van der Heyden, 1989b]. Only a thin metamorphic selvage of the Upper Jurassic volcanic cover is preserved in northwestern British Columbia, whereas to the north in southeast Alaska, a relatively thick, volcanic section is preserved and is partly affected by low-grade metamorphism. Deeper levels of the arc also are preserved to the north in the St. Elias Range and the southern Yukon Territory. Late Jurassic to earliest Cretaceous calcalkaline plutonism occurred throughout the Alexander terrane and locally within Wrangellia [Dodds and Campbell, 1988]. Coeval calcalkaline plutonism also extended into southern Alaska [MacKevett, 1978; Hudson, 1983] and northem southeastern Alaska [Brew and Morrell, 1983]. Volcanic strata of this age have not been recognized at those latitudes; however, the Upper Jurassic and Lower Cretaceous arc-related strata of the Gravina sequence in southeast Alaska may represent the upper crustal levels of the Late Jurassic plutonic belt. The differences in level of exposure of Early Cretaceous between southeast Alaska and western British Columbia are probably due to Late Jurassic to Early Cretaceous arc-parallel strike-slip faulting, along strike variations of mid-Cretaceous thrust faulting, and differential post mid-Cretaceous uplift, extension and erosion. This interpretation may explain the paucity of Upper Jurassic volcanic rocks in western British Columbia, Yukon, and southern Alaska.

\section{CONCLUSIONS}

Basaltic to andesitic lavas and pyroclastic strata of the Gravina-Nutzotin belt in southeastern and southern Alaska delineate a Late Jurassic to Early Cretaceous arc system. Arc volcanism was probably intermittent from middle Late Jurassic to Late Jurassic through Early Cretaceous. The arc was constructed across a composite basement consisting of the Alexander and Wrangellia terranes, and likely correlatives of the Stikine and Yukon-Tanana terranes, requiring a pre-Late Jurassic tie between Insular composite terrane and the western margin of North America. The Jurassic volcanic strata are dominated by tholeiitic arc basalts that were shed from the flanks of submarine volcanos. Fine- to coarse-grained epiclastic turbidites were deposited in a submarine fan setting adjacent to dissected volcanic centers. Abundant Late Jurassic granitic cobbles in the clastic basinal deposits and the absence of Aptian strata locally record uplift and erosion of the arc. Volcanic activity was diachronous along the island arc and may reflect segmentation of the arc or incomplete preservation. The volcanic and basinal rocks of the Gravina sequence were deformed during a major intra-arc contractional event during mid-Cretaceous time, accompanied by emplacement of a distinctly younger (90-100 Ma) arc-related plutonic suite.

Acknowledgments. Parts of this research were supported by National Science Foundation grants EAR 86-05386 and EAR 88034834 (to Saleeby). Additional support (to Rubin) was provided by a Geological Society of America Penrose Grant, a Sigma-Xi grant-in-aid, the U.S. Geological Survey, Alaska Branch, and by the U.S. Forest Service, Ketchikan Ranger District. Jeff Marshall provided excellent field assistance during the summer of 1987. We thank Fred Barker, Darrel Cowan, Weecha Crawford, John Garver, George Gehrels, Linc Holllister Bill McClelland, Meghan Miller, Jim Monger, and George Plafker for helpful discussions. George Plafker provided a very thorough and constructive review of the manuscript. Special thanks to Fred Barker (U.S. Geological Survey) for providing the geochemical analyses for the Gravina sequence volcanic rocks.

\section{REFERENCES}

Armstrong, R. L. , Mesozoic and early Cenozoic magmatic evolution of the Canadian Cordillera, Spec. Pap. Geol. Soc. Am., 218, 55-91, 1988 .

Barker, F., Cretaceous Chisana island arc of Wrangellia, eastem Alaska, Geol. Soc. Am. Abstr. Programs, 19(7), 580, 1987.

Barker, F., A. Sutherland-Brown, J. R., Budahn, G., Plafker, Back-arc with frontal-arc component origin of Triassic Karmutsen basalt, British Columbia, Canada, Chem. Geol. 75, 81-102, 1989.

Beikman, H. M., Geologic map of Alaska, Spec. Map, 1:5,000,000, U.S. Geol. Survey, Reston Va., 1980.

Berg, H. C., Geologic map of Annette Island, Alaska, U.S. Geol. Surv. Misc. Invest. Map I-684, 1972.

Berg, H. C., Geology of Gravina Island, Alaska, U.S. Geol. Surv. Bull., 1373, 41 Pp., 1973.

Berg, H.C., and E. L. Cruz, Map showing locations of fossil collections and related samples in the Ketchikan and Prince Rupert quadrangles, southeastern Alaska, U.S. Geol. Surv. Open-File Report 82-1088, 1982.

Berg, H. C., D. L. Jones, and D. H. Richter, Gravina-Nutzotin belt: Tectonic significance of an upper Mesozoic sedimentary and volcanic sequence in southem and southeastem Alaska, U.S. Geol. Surv. Prof. Pap., 800-D, D1- D24, 1972.

Berg, H. C., R. L. Elliott, and R. D. Koch, Geologic map of the Ketchikan and Prince Rupert quadrangles, Alaska, U.S. Geol. Surv. Misc. Invest. Map, 1-1807, 1988.

Berg, H. C., D. L. Jones, and D. H. Richter, Gravina-Nutzotin belt: Tectonic significance of an upper Mesozoic sedimentary and volcanic sequence in southem and southeastem Alaska, U.S. Geol. Surv. Prof. Pap., 800-D, D1- D24., 1972.

Brew, D. A., and A. B. Ford, Preliminary geologic map of the Juneau, Taku River, Atlin, and parts of the Skagway quadrangles, southeast Alaska, U.S. Geol. Surv. Open File Rep., 85-395, 1985.

Brew, D. A., and S. M. Karl, Reexamination of the contacts and other features of the Gravina belt, southeastem Alaska, U.S. Geol. Surv. Circ., 1016, 143-146, 1987.

Brew, D. A., and R. P. Morrell, Intrusive rocks and plutonic belts in southeastem Alaska, U.S.A., Circum-Pacific Plutonic terranes, edited by J.A. Roddick, Mem. Geol. Soc. Am. Mem., 159 171- 194, 1983.

Brew, D. A., R. A. Loney, and L. J. P. Muffler, Tectonic history of southeastem Alaska, in A symposium on the tectonic history and mineral deposits of the westem Cordillera in British Columbia and neighboring part of the United States, Spec. Vol. Can. Inst. Mining and Metall., 8, 149-170, 1966.

Brooks, A. H., Preliminary report on the Ketchikan mining district, Alaska, with a reconnaissance of Chickaman River, U.S. Geol. Surv. Prof. Pap., 1, 120 pp., 1902.

Buddington, A. F., and T. Chapin, Geology and mineral deposits of southeastem Alaska, U.S. Geol. Surv. Bull., 800, 398 pp., 1929.

Busby-Spera, C. J., Evolution of a Middle Jurassic back-arc basin, Cedros Island, Baja California, Evidence from a marine volcaniclastic apron, Geol. Soc. Am. Bull., 100, 218-233, 1988.

Cameron, A. E., D. H. Smith, and D. H. Walker, Mass spectrometry of nanogram-size samples of lead, Aral. Chem., 41, 525-526, 1969.

Cann, J. R., Rb, $\mathrm{Sr}, \mathrm{Y}, \mathrm{Zr}$, and $\mathrm{Nb}$ in some ocean-floor basaltic rocks, Earth Planet. Sci. Lett., 19, 7-11, 1970

Chapin, T., The structure and stratigraphy of Gravina and Revillagigedo Islands, Alaska, U.S. Geol.Surv. Prof. Pap., 120-D, $83-100,1918$.

Chen, J. H., and G. J. Wasserburg, Isotopic determination of uranium in picomole and subpicomole quantities, Anal. Chem., 53, 2060 2067, 1981.

Crawford, M. L., L. S. Hollister, and G. J. Woodsworth, Crustal deformation and regional metamorphism across a terrane boundary, Coast Plutonic Complex, British Columbia, Tectonics, 6, 343-361, 1987.

Dodds, C. J., and R. B. Campbell, Potassium-argon ages of mainly intrusive rocks in the Saint Elias Mountains, Yukon and British Columbia, Pap. Geol. Surv. Can.s 87-16, 43 pp., 1988.

Douglas, R. J., H. Gabrielse, J. O. Wheeler,.D. F., Scott, and H. R. 
Belyea, Geology of westem Canada, Rep. 1, Can. Geol. Surv., Ottawa, pp. 365-448, 1970.

Engebretsen, D. C., A. Cox, and R. G. Gordon, Relative motions between oceanic and continental plates in the Pacific basin, Spec. Pap. Geol. Soc. Am., 206, 59 pp., 1985.

Ford, A. B., and Brew, D. A., Major-element geochemistry of the metabasalts of the Juneau-Haines region, southeast Alaska, U.S. Geol. Surv. Circ., 1016, 150-155, 1987

Gabrielse, H., Major dextral transcurrent displacements along the Northem Rocky Mountain trench and related lineaments in northcentral British Columbia, Geol. Soc. Am. Bull., 96, 1-14, 1985.

Gabrielse, H. and J. O. Wheeler, Tectonic framework of southern Yukon and northwestem British Columbia, Pap. Geol. Surv. Can., 60-24, 37, 1961.

Garcia, M. O., Criteria for the identification of ancient volcanic arcs, Earth Sci. Rev., 14, 147-165, 1978.

Gehrels, G. E., and W. C. McClelland, Outline of the Taku terrane and Gravina belt in the Cape Fanshaw-Windham Bay region of central southeastem Alaska, Geol. Soc. Am. Abstr. Programs, 20, 163, 1988.

Gehrels, G. E., and J. B. Saleeby, Geologic framework, tectonic evolution and displacement history of the Alexander terrane, Tectonics, 6, 151-173, 1987a.

Gehrels, G. E., and J. B. Saleeby, Geology of Annette, Gravina, and Duke islands, southeastem Alaska, Can.J. Earlh Sci., 24, 866-881, $1987 b$.

Gehrels, G. E., W. C. McClelland, S. D. Samson, P. J. Patchett, and J. L. Jackson, Ancient continental margin assemblage in the northem Coast Mountains, southeast Alaska and northwest Canada, Geology, 18, 208-211, 1990.

Gehrels, G. E., W. C. McClelland, S. D. Samson, and P. J. Patchett, U$\mathrm{Pb}$ geochronology of detrital zircons from the Yukon crystalline terrane in the northern Coast Mountains batholith, southeastem Alaska, Can. Jour. Earth Sci., in press, 1991.

Gill, J., Orogenic Andesites and Plate Tectonics, 385 pp. SpringerVerlag, New York, 1981.

Grantz, A., D. L. Jones, and M. A. Lanphere, Stratigraphy, paleontology, and isotopic ages of upper Mesozoic rocks in the southwestem Wrangell Mountains, Alaska, U.S. Geol. Surv. Prof. Pap., 550-C, C39-C47, 1966.

Harland, W. B., A. V. Cox, P. G. Lewellyn, C. A. G. Pickton, A. G. Smith, and R. Walters, A Geologic Time Scale, 131 pp., Cambridge University Press, New York, 1982.

Hawkins, J. W., G. F. Moore, R. Villamor, C. Evans, and E. Wright, Geology of the composite terrane of east and central Mindanao, Earth Sci. Ser., vol. 1, pp. 437-463, Circum-Pacific Council for Energy and Mineral Resources, Housion, Texas, 1985.

Hollister, L. S., G. C. Grissom, E. K. Peters, H. H. Stowell, and V. B. Sisson, Confirmation of empirical correlation of Al in homblende with pressure of solidification of calc-alkaline plutons, Am. Min., 72, $231-239,1987$.

Hudson, T., Calc-alkaline plutonism along the Pacific rim of Southem Alaska, in edited by J.A. Roddick, Circum-Pacific Plutonic terranes, Mem Geol. Soc. Am. 159, 159-1170, 1983.

Humphris, S. E., and G. Thompson, Trace-element mobility during hydrothermal alteration of oceanic basalts, Geochim. Cosomochim. Acta, 42, 127-136, 1978.

Imlay, R. W., Early Cretaceous (Albian) ammonites from the Chitna Valley and Talkeetna Mountains, Alaska, U.S. Geol. Surv. Prof. Paper 354-D p. 87-114, 1960.

Jaffey, A. H., K. F. Flynn, L. E. Glendenin, W. C. Bentley, and A. M. Essling, Precision measurement of half-lives and specific activities of 235U and 238U, Phys. Rev. C, 4, 1889-1906, 1971.

Jones, D. L.,Cretaceous ammonites from the lower part of the Matanuska Formation, southem Alaska, U.S. Geol. Surv. Prof. Paper 547, 49 pp., 1967.

Karig, D. E., Origin and development of marginal basins in the westem Pacific, J. Geophys. Res., 76, 2541-2561, 1971.

Karig. D. E., Accreted terranes in the northem part of the Philippine Archipelago. Tectonics, 2, 211-236, 1983.

Karig, D. E., and G. F. Moore, Tectonically controlled sedimentation in marginal basins, Earth Planet. Sci. Lett., 26. 233-238, 1975.

Karl, S. M., B. R. Johnson, and M. A. Lanphere, New K-Ar ages for plutons on western Chichagof Island on on Yakobi Island, U.S. Geol. Surv. Circ., 1016, 164-168, 1987.

Kay, R. W., Volcanic arc magmas: Implications of a melting-mixing model for element recycling in the crust-upper mantle system, $J$. Geol., 88, 497-522, 1980.

Klein, G. de V., The control of depositional depth, tectonic uplift, and volcanism on sedimentation processes in backarc basins of the western Pacific, J. Geol., 93, 1-25, 1985.

Krogh, T. E., A low-contamination method for hydrothermal decomposition of zircon and extraction of $\mathrm{U}$ and $\mathrm{Pb}$ for isotopic age determinations, Geochim. Cosomochim. Acta, 37, 485-494, 1973.

Loney, R. A., D. A. Brew, L. J. P. Muffler, and J. S. Pomeroy, Reconnaissance geology of Chichagof, Baranof, and Kruzof Islands, southeastem Alaska, U.S. Geol. Surv. Prof. Pap., 792, 105 pp., 1973.

Lowe, P.C., D. H. Richter, R. L. Smith, and H. R. Schmoll, Geologic map of the Nabesna B-5 quadrangle, Alaska, U.S. Geol. Surv. Quadrangle Map. GQ-1566, 1982.

MacKevett, E. M., Jr., Geologic map of the McCarthy quadrangle, Alaska, U.S. Geol. Surv. Misc. Invest. Map, I-1031, 1978.

Mattinson, J. M., U.Pb ages of zircon: a basic examination of error propagation, Chem. Geol., 66, 151-162, 1987.

May, S. R., and R. F. Butler, North American Jurassic apparent polar wander: Implications for plate motion, paleogeography and Cordilleran tectonics, J. Geophys. Res., 91, 11,519-11,544, 1986.

McClelland, S. M., and S. R. Taylor, Role of subducted sediments in island-arc magmatism: Constraints from REE patterns, Earth Planet. Sci. Lett., 54, 423-430, 1981.

McClelland, W. C., and G .W. Gehrels, Geology of the Duncan Canal shear zone: Evidence for Early to Middle Jurassic deformation of the Alexander terrane, Geol. Soc. Am. Bull., 102, 1378-1392, 1990.

Monger, J. W. H., and H. C. Berg. Lithotectonic terrane map of westem Canada and southeastem Alaska: U.S. Geol. Surv. Misc. Map MF-1874B, 1987.

Monger, J. W. H., R. A. Price, and J. D. Tempelman-Kluit, Tectonic accretion and the origin of the two major metamorphic and plutonic welts in the Canadian Cordillera, Geology, 10, 70-75. 1982.

Moorbath, W, and S. Hildreth, Crustal contamination to arc magmatism in the Andes, Contr. Min. Petrol., 98, 455-489, 1988.

Nakumara, N., Determination of REE, $\mathrm{Ba}, \mathrm{Fe}, \mathrm{Mg}, \mathrm{Na}$, and $\mathrm{K}$ in carbonaceous and ordinary chondrites, Geochim. Cosmochim. Acla, 38, 757-775, 1974.

Oldow, J. S., A. W. Bally, H G. Ave Lallemant, W. P Leeman, Phanerozoic evolution of the North American Cordillera: United States and Canada, The Geology of North America, in The Geology of North America - An Overview, vol. A, edited by A.W. Bally and A.R. Palmer, PP. 139-232, Geological Society of America, Boulder, Colo., 1989.

Pavlis, T. J., Origin and age of the Border Ranges Fault of southem Alaska and its bearing on the Late Mesozoic tectonic evolution of Alaska, Tectonics, 1, 343-368, 1982.

Pearce, J. A., Trace element characteristics of lavas from destructive boundaries, in Andesiles, Orogenic Andesites and Related Rocks, edited by R.S. Thorpe, pp. 525-547, John Wiley, New York, 1982.

Pearce, J. A., Role of the sub-continental lithosphere in magma genesis at active continental margins, in Continental Basalts and Mantle Xenoliths, edited by C.J. Hawkesworth and M.J. Norry, pp. 230-259, Birkhauser Boston, Secaucus, N. J., 1983.

Pearce, J. A., and J. R. Cann, Teclonic setting of basic volcanic rocks determined using trace element analyses, Earth Planet. Sci. Lett., 19, 290-300, 1973.

Pearce. J. A., and M. J. Norry, Petrogenetic implications of Ti, Zr, Y, and $\mathrm{Nb}$ variations in volcanic rocks, Contrib. Mineral. Petrol., 69, 33-47, 1979.

Pearce, J. A., Lippard, S. J., and Roberts, S., Characteristics and tectonic significance of supra-subduction zone ophiolites, in Marginal basin geology: Volcanic and associated sedimentary and tectonic processes in modern and ancient marginal basins, edited by B.P. Kokelaar and M.F. Howells, pp. 77-94, Blackwell Scientific Publications, Oxford, England, 1984.

Plafker, G., W. J. Nockleberg, and J. S. Lull, Bedrock geology and tectonic evolution of the Wrangellia, Peninsular, and Chugach terranes along the trans-Alaskan crustal transect in the Chugach 
Mountains and southem Copper River Basin, Alaska, J. Geophys. Res., 94, 4255-4295, 1989a.

Plafker, G., C. D. Blome, and N. J. Silberling, Reinterpretation of lower Mesozoic rocks on the Chilkat Peninsula, Alaska, as a displaced fragment of Wrangellia, Geology, 17, 3-6, $1989 \mathrm{~b}$.

Richter, D. H., Geologic map of the Nabesna quadrangle, Alaska, U.S. Geol. Surv. Misc., Invest. Map, I-932, 1976.

Richter, D. H , and D. L. Jones, Structure and stratigraphy of eastem Alaska Range, Mem. Am. Assoc. Pet. Geol., 19, 408-420, 1973.

Rubin, C. M., and J. B. Saleeby, The inner boundary zone of the Alexander terrane in southem SE Alaska, A newly discovered thrust belt, Geol. Soc. Am. Abstr. Programs, 19, 455, 1987.

Rubin, C. M., and J. B. Saleeby, Tectonic framework of upper Paleozoic and lower Mesozoic Alava sequence: $A$ revised view of the polygenetic Taku terrane in southern southeast Alaska, Can. J. Earth Sci., in press, 1991.

Rubin, C. M., M. M. Miller, and G. E. Smith, Tectonic development of Cordilleran mid-Paleozoic volcanoplutonic complexes: Evidence for convergent margin tectonism, Spec. Pap. Geol. Soc. Am., 225, $1-16,1990 a$.

Rubin, C. M., J. B. Saleeby, D. S. Cowan, M. T. Brandon, and M. F. McGroder, Regionally extensive mid-Cretaceous west-vergent thrust system in the northwestem Cordillera: Implications for continent-margin tectonism, Geology, 18 (3), 276-280, 1990 b.

Saleeby, J. B., Accretionary tectonics of the North American Cordillera, Annu. Rev. Earth Planet. Sci., 15, 45-73, 1983.

Saleeby, J. B., The inner boundary zone of the Alexander terrane in southern SE Alaska: Part II southem Revillagigedo Island (RI) to Cape Fox (CF), Geol. Soc. Am. Abstr. Programs, 19, 828, 1987.

Samson, S. D., W. C. McClelland, P. J. Patchett, and G. E. Gehrels, Nd isotopes and Phanerozoic crustal genesis in the Canadian Cordillera, Nature, 337, 705-709, 1989.

Silberling, N. J., B. R. Wardlaw, and H. C. Berg, New paleontologic age determinations from the Taku terrane, Ketchikan area, southeastern Alaska, U.S. Geol. Surv. Circ. 844, 117-119, 1981.

Smith, P. S., Notes on the geology of Gravina Island, Alaska, U.S. Geol. Surv. Prof. Pap., 95, 97-105, 1915.

Terra, F., and G .S. Wasserburg, U-Th-Pb systematics in three Apollo 14 Basalts and the problems of the initial $\mathrm{Pb}$ in lunar rocks, Earth Planet. Sci. Lett., 14, 281-304, 1972.

Thompson, R. N., Magmatism of the British Tertiary province, Scott. J. Geol., 18, 49-107, 1982.
Thorpe, R. S., Andesites: Orogenic Andesites and Related Rocks, 724 pp., John Wiley, New York, 1982.

Van Der Heyden, P., Jurassic magmatism and deformation: Implications for the evolution of the Coast Plutonic Complex, Geol. Soc. Am. Abstr. Programs, 21, 153, 1989a.

Van Der Heyden, P., U-Pb and K-Ar geochronometry of the Coast Plutonic Complex, $53^{\circ} \mathrm{N}-54^{\circ} \mathrm{N}$, and implications for the InsularIntermontane superterrane boundary, British Columbia, Ph.D. thesis, Univ. of British Columbia, Vancouver, $1989 b$.

Wheatley, M., and N. M. S. Rock, SPIDER: A Macintosh program to generate normalized multi-element "spidergrams," Am. Min., 73, 919-921, 1988.

Wheeler, J. O., and P. McFeely, Tectonic assemblage map of the Canadian Cordillera. Open-File Rep., 1565, Can. Geol. Surv., Ottawa, 1987.

White, W. M., and B. Dupré, Sediment subduction and magma genesis in the Lesser Antilles: Isotopic and trace element constraints, $J$. Geophys. Res., 91, 5927.5941, 1986.

Winchester, J. A., and P. A. Floyd, Geochemical discrimination of different magma series and their differentiation products using immobile elements, Chem. Geol., 20, 325-343, 1973.

Winchester, J. A., and P. A. Floyd, Geochemical discrimination of different magma series and their differentiation products using immobile elements, Chem., Geol., 325-343, 1977.

Woodsworth, G. J . M. L. Crawford, and L. S. Hollister, Metamorphism and structure of the Coast Plutonic Complex and adjacent belts, Prince Rupert and Terrace areas, British Columbia, Field Trip Guidebook 14, 62 pp., Geological Association of Canada, Waterloo, Ont. 1983.

Wright, F. E., and C. W. Wright, The Ketchikan and Wrangell mining districts, Alaska, U.S. Geol. Surv. Bull., 347, 210 pp., 1908.

York, D., Least-squares fining of a straight line with correlated errors, Earth Planet. Sci. Lett., 5, 320-324, 1969.

C. M. Rubin and J. B. Saleeby, Division of Geologic and Planetary Sciences, Califomia Institute of Technology, Pasadena, CA 91125.

(Received August 2, 1990; revised February 19, 1991; accepted February 23, 1991.) 